\title{
Microbial activity and carbonate isotope signatures as a tool for identification of spatial differences in methane advection: a case study at the Pacific Costa Rican margin
}

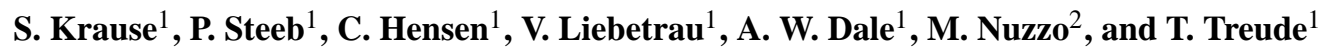 \\ ${ }^{1}$ GEOMAR Helmholtz Centre for Ocean Research Kiel, Wischhofstr. 1-3, 24148 Kiel, Germany \\ ${ }^{2}$ IDL, University of Lisbon, Lisbon, Portugal \& Portuguese Institute for the Sea and Atmosphere (IPMA), Lisbon, Portugal
}

Correspondence to: S. Krause (skrause@geomar.de) and T. Treude (ttreude@geomar.de)

Received: 29 March 2013 - Published in Biogeosciences Discuss.: 15 May 2013

Revised: 11 October 2013 - Accepted: 22 November 2013 - Published: 31 January 2014

\begin{abstract}
The forearc of the convergent margin offshore Costa Rica is a region characterized by strong advection of methane-charged fluids causing the formation of ubiquitous cold seeps (mounds). Presented here are the first measurements of microbial anaerobic oxidation of methane $(\mathrm{AOM})$ and sulfate reduction (SR) rates in sediments from two mounds (11 and 12), applying radiotracer techniques in combination with numerical modelling. In addition, analysis of microbial, methane-dependent carbonate $\delta^{18} \mathrm{O}$, $\delta^{13} \mathrm{C}$, and ${ }^{87} \mathrm{Sr} /{ }^{86} \mathrm{Sr}$ signatures constrained the origin of the carbonate-precipitating fluid. Average rates of microbial activities differed by a factor of $\sim 5$ to 6 between Mound 11 (AOM 140.71 ( $\pm 40.84 \mathrm{SD}) \mathrm{mmol} \mathrm{m}^{-2} \mathrm{~d}^{-1}$, SR 117.25 ( $\pm 82.06 \mathrm{SD}) \mathrm{mmol} \mathrm{m}^{-2} \mathrm{~d}^{-1}$ ) and Mound 12 (AOM $22.37( \pm 0.85 \mathrm{SD}) \mathrm{mmol} \mathrm{m}^{-2} \mathrm{~d}^{-1}$, SR 23.99 ( $\left.\pm 5.79 \mathrm{SD}\right)$ mmol m $\left.\mathrm{m}^{-2} \mathrm{~d}^{-1}\right)$. Modelling results yielded upward fluid advection velocities of $200 \mathrm{~cm} \mathrm{yr}^{-1}$ at Mound 11 and $15 \mathrm{~cm} \mathrm{yr}^{-1}$ at Mound 12. Analysis of oxygen and carbon isotope variations of authigenic carbonates from the two locations revealed more enriched values for Mound 11 $\left(\delta^{18} \mathrm{O}: 3.18\right.$ to $6.15 \%$; $\delta^{13} \mathrm{C}:-14.14$ to $-29.56 \%$ ) compared to Mound $12\left(\delta^{18} \mathrm{O}: 3.09\right.$ to $4.48 \%$; $\delta^{13} \mathrm{C}:-39.53$ to $-48.98 \%$ ). The variation of carbonate ${ }^{87} \mathrm{Sr} /{ }^{86} \mathrm{Sr}$ indicated considerable admixture of deep-source fluid at Mound 11, while seawater ${ }^{87} \mathrm{Sr} /{ }^{86} \mathrm{Sr}$ characteristics prevailed at Mound 12 during precipitation. The present study is in accordance with previous work supporting considerable differences of methane flux between the two mounds. It also strengthens the hypothesis of a dominant deep fluid source with thermogenic methane at Mound 11 versus a shallow source of
\end{abstract}

biogenic methane at Mound 12. The results demonstrate that measurements of methane-driven microbial activity in combination with numerical modelling are a valid tool for constraining recent methane fluxes in the study area. In addition, the analysis of methane-derived authigenic carbonates provides an independent line of evidence for long-term fluid contribution to the porewater chemistry of shallow sediments in the study area.

\section{Introduction}

Fluid emanation at the seafloor is a common feature occurring in forearcs of convergent margins. The most important mechanisms that create fluid overpressuring and expulsion are tectonic compression, rapid burial of underconsolidated sediments, the release of mineral-bound water, the formation of gas from the biogenic or thermogenic breakdown of organic material, and the dissolution of gas hydrates (Kopf, 2002; Saffer et al., 2011). Compressional release of porewater and the release of mineral-bound water from subducting sediments are thought to play a major role in terms of fluid cycling in the forearc of the Costa Rican margin (Hensen et al., 2004; Ranero et al., 2008).

When these fluids exit the sediment surface, they form what is commonly known as cold seeps. Cold-seep systems can be associated with different geological structures such as crater-like structures (pockmarks) or mud extrusions (mounds, volcanoes) (Judd et al., 2002). These systems are often characterized by authigenic carbonate concretions of 
micritic crystal morphology (Naehr et al., 2007), produced by microbial anaerobic oxidation of methane (AOM) in the sediment (e.g. Bohrmann et al., 1998; Greinert et al., 2001; Suess, 2010).

The prerequisite for microbial-related authigenic carbonates at cold seeps is the advection of methane $\left(\mathrm{CH}_{4}\right)$. In marine sediments, methane is formed either as the result of microbial (biogenic methane) or thermal (thermogenic methane) degradation of organic matter (Schoell, 1988; Thauer, 1998). Thermogenic methanogenesis is either facilitated by (1) pyrolysis of organic matter or (2) water-rock interaction, resulting in different carbon isotope signatures compared to biogenic methane formation (Whiticar, 1999).

In anoxic sediments, methane removal is mediated by microbial, sulfate $\left(\mathrm{SO}_{4}^{2-}\right)$ - dependent AOM (Boetius et al., 2000). The general reaction of AOM is (Barnes and Goldberg, 1976)

$$
\mathrm{CH}_{4}+\mathrm{SO}_{4}^{2-} \rightarrow \mathrm{HCO}_{3}^{-}+\mathrm{HS}^{-}+\mathrm{H}_{2} \mathrm{O} \text {. }
$$

$\mathrm{AOM}$ and sulfate reduction (SR) increase porewater alkalinity, producing bicarbonate $\left(\mathrm{HCO}_{3}^{-}\right)$, which can dissociate into carbonate $\left(\mathrm{CO}_{3}^{2-}\right)$. In the case of supersaturation, carbonate minerals may form, predominantly with $\mathrm{Ca}^{2+}$ ions (Peckmann et al., 2001). The chemical and isotopic composition of authigenic carbonate provides information regarding the fluids present at the site of precipitation (Naehr et al., 2007; Peckmann et al., 2001). Therefore, authigenic carbonates represent a suitable archive of the palaeohydrological and geological settings present during precipitation.

Here, we report the first rate measurements of AOM and SR as well as carbonate mineralogy and isotopy from two adjacent mud extrusions (Mound 11 and 12) located at the subduction zone forearc off the Pacific Costa Rican coast. In addition, a numerical model, constraining fluxes of the main chemical species in the porewater, is presented. An accessory data set of strontium isotopic signatures from carbonates obtained during previous cruises is also included, representing a supporting indicator for potentially different fluid sources and their contribution to mineral composition during precipitation. Both mound structures have been extensively studied (e.g. Hensen et al., 2004; Schmidt et al., 2005; Mavromatis et al., 2012), focusing mound-specifically on either individual geological or biogeochemical aspects. Here, we directly compare the geochemical situation of the two mounds and characterize differences, especially emphasizing methane advection and resulting microbial activity applying on-board techniques.

\section{Material and methods}

\subsection{Geological settings and study sites}

The Middle American Trench is a large-scale subduction zone with a length of $2750 \mathrm{~km}$ located off the south-western coast of Central America. Offshore Costa Rica, the trench is formed by the eastward subduction of the oceanic Cocos Plate beneath the Caribbean Plate. A characteristic feature of this trench is the subduction of seamounts and ridges (Ranero and Von Huene, 2000). As these structures are thrusted into and below the continental plate, subduction of material may cause fractures in the upper plate and overlying shelf sediments through which fluids rise towards the surface (Ranero et al., 2008).

Fluid emanation off Costa Rica predominantly occurs at bathymetric elevations, so-called mounds, which are ubiquitous and composed of authigenic carbonates, mud extrusions, and hemipelagic sediments (Hensen and Wallmann, 2005). The present study focuses on the two neighbouring mounds, Mound 11 and 12 (Figs. 1 and 2), which are situated northeast of the Osa Peninsula (Greinert et al., 2001; Bohrmann et al., 1998) at water depths of $\sim 1000 \mathrm{~m}$ (Klaucke et al., 2008).

Mound 11 is located at $08^{\circ} 55^{\prime} 20^{\prime \prime} \mathrm{N}$ and $-84^{\circ} 18^{\prime} 14^{\prime \prime} \mathrm{W}$ and has two summits that are $\sim 300 \mathrm{~m}$ apart and $\sim 250 \mathrm{~m}$ in diameter (Klaucke et al., 2008). Previous investigations, including sediment sampling and video survey, showed that the surface of Mound 11 consists of fine-grained sediment with mats of sulfur bacteria (Mau et al., 2006; Mörz et al., 2005; Schmidt et al., 2005).

Mound 12 is located about $1 \mathrm{~km}$ north of Mound 11 and is characterized by a differing geological morphology, including a solitary summit with a diameter of $\sim 800 \mathrm{~m}$ (Klaucke et al., 2008). Sediment sampling and video surveys of the sediment surface revealed fine-grained sediment and typical cold-seep features, such as mats of sulfur-oxidizing bacteria, fields of chemosymbiotic vesicomyid clams, and carbonate precipitates (Linke et al., 2005; Mau et al., 2006).

\subsection{Sediment and carbonate sampling}

Sediment samples from Mound 11 and 12 were obtained during the research expedition SO206 (June 2010) on board the German RV Sonne. Stations for sediment recovery on both mounds were situated at water depths of $1000-1010 \mathrm{~m}$ (Table 1). Samples were collected with a gravity corer (GC) (barrel length $6 \mathrm{~m}$ ) and a video-guided multicorer (MUC) consisting of eight core liners per deployment, each $60 \mathrm{~cm}$ long and $10 \mathrm{~cm}$ in diameter. MUC sampling was performed at locations with microbial mats of filamentous sulfur-oxidizing bacteria visible on the sediment surface, indicating areas of high methane flux (Torres et al., 2004; Treude et al., 2003). The obtained carbonates from GC and MUC samples varied in size from centimetres to decimetres, forming irregular, elongated, and flattened nodules. The carbonate nodules were picked from GC and MUC cores using gloves, wrapped in aluminium foil, and subsequently stored at $-20^{\circ} \mathrm{C}$. Two bivalve shell fragments found within sediment from SO206-39 (MUC) were sampled in the same way. In addition, strontium isotope ratios of carbonate samples obtained from Mound 11 and 12 during three previous cruises 
SO173/4 (September 2003) on board the RV Sonne, M66/3a (October-November 2005), and M54/3a (September 2002) on board the RV Meteor (Table 1) were also used in this study. An overview of carbonate samples taken from GC and MUC cores is given in Table 2.

\subsection{Core processing for porewater extraction}

The GC obtained at station SO206-50 (length $300 \mathrm{~cm}$ ) was sectioned into $1 \mathrm{~m}$ intervals and cut in half vertically. One half was stored at $4{ }^{\circ} \mathrm{C}$, serving as archive, whilst the other half was used for sediment and porewater sampling. Nine samples for porewater extraction were obtained at $30-45 \mathrm{~cm}$ intervals over a total length of $300 \mathrm{~cm}$. From each MUC cast (Mound 11, SO206-39; Mound 12, SO206-44 and 46), one core was assigned for sediment porewater analysis and sampled at 10 discrete $1 \mathrm{~cm}$ depth intervals from the surface down to the bottom of the core.

\subsection{Porewater analysis}

Porewater was extracted from sediments using a pressure filtration system (argon 3-4 bar, $0.2 \mu \mathrm{m}$ regenerated cellulose filters). Retrieved porewater was analysed on board for total alkalinity (TA) and total dissolved sulfide concentrations. Additional porewater samples were stored frozen for further measurements on land.

For TA determination, $1 \mathrm{~mL}$ of porewater was titrated manually with $0.01 \mathrm{M} \mathrm{HCl}$ using an open cell and a Metrom Titrino plus titration unit. A methyl red-methylene blue solution with the following composition was used as indicator: sodium salt of methyl red $(37 \mathrm{mg})$ was mixed with $1.19 \mathrm{~mL}$ of $0.1 \mathrm{M} \mathrm{NaOH}$ and dissolved in $80 \mathrm{~mL}$ of ethanol (96\%) (solution 1). Methylene blue $(10 \mathrm{mg})$ was dissolved in $10 \mathrm{~mL}$ of ethanol (96\%) (solution 2). Both solutions were mixed ( $80 \mathrm{~mL}$ of solution 1 and $4.8 \mathrm{~mL}$ of solution 2) to obtain a greenish-brown product. IAPSO standard seawater was used for TA calibration. Hydrogen sulfide concentration measurements were carried out photometrically after Cline (1969). For sulfide calibration, Titrisol ${ }^{\circledR}$ standard $0.1 \mathrm{~N} \mathrm{Na}_{2} \mathrm{~S}_{2} \mathrm{O}_{3}$ was used. For sulfate measurements, porewater samples were acidified with ultra-purified $\mathrm{HNO}_{3}(65 \%)$ and cooled to $4{ }^{\circ} \mathrm{C}$ until further use. Sulfate and chloride concentrations were determined using ion chromatography (METHROM 761) at GEOMAR laboratory, Kiel. The determination of main and trace elements was carried out using atomic emission spectroscopy with inductively coupled plasma atomic emission spectroscopy (ICP-AES) at GEOMAR, Kiel.

Methane was stripped on board from sediments according to the method of McAullife (1971). Sediment plugs were recovered using clean, disposable $10 \mathrm{~mL}$ polypropylene syringes with the end removed. The sediment plug was immediately transferred to a $30 \mathrm{~mL}$ glass vial filled with $10 \mathrm{~mL}$ of $10 \%$ aqueous potassium chloride $(\mathrm{KCl})$ solution. The vial was sealed and vigorously shaken to disaggregate the mud and to stop all bacterial activity (Bowes and Hornibrook, 2006). The sample was stored upside down to minimize potential gas exchange with the atmosphere and allowed to equilibrate with the vial headspace for $48 \mathrm{~h}$. The gas was then extracted with a syringe while injecting an equivalent amount of $10 \% \mathrm{KCl}$ solution. A blank sample (air equilibrated with $10 \% \mathrm{KCl}$ solution) was taken for background corrections. The $\mathrm{KCl}$ solution was not acidified so as to avoid production of $\mathrm{CO}_{2}$ by dissolution of carbonate minerals. The headspace gas was injected into either 10 or $20 \mathrm{~mL}$ sterile serum vials filled (bubble-free) with acidified ( $\mathrm{pH} \mathrm{1)}, 10 \% \mathrm{KCl}$ solution to terminate any microbial activity, whilst displacing an equivalent amount of solution. The vials were stored upside down until analysis. The methane concentration was determined on board by gas chromatography coupled to a flame ionization detector (GC-FID) using a Shimadzu GC14A instrument fitted with a Restek Rt ${ }^{\circledR}$ Alumina Bond/ $/ \mathrm{Cl}$ capillary column $(50 \mathrm{~m}, 0.53 \mathrm{~mm} \mathrm{ID})$ operated at $60^{\circ} \mathrm{C} . \mathrm{N}_{2}$ was used as a carrier gas.

\subsection{Sediment sampling for ex situ microbial turnover rates of methane and sulfate}

Immediately after retrieval of the MUC, six replicate polycarbonate push cores (three for AOM rates, three for SR rates; inner diameter $26 \mathrm{~mm}$, length $25 \mathrm{~cm}$ ) were sampled from pristine surface sediment from one MUC liner. Open ends of push cores were sealed tightly with rubber stoppers, avoiding air entrapment. Sediment from gravity corers was sampled with six $5 \mathrm{~mL}$ glass tubes, closed with syringe puncheons, and dipped in Antifoam ${ }^{\circledR}$ to enable a better gliding. In addition, 10 controls ( $5 \mathrm{~mL}$ each) were sampled from anoxic sediment of the same core (GC or MUC) using $5 \mathrm{~mL}$ syringes with cut-off tips. For sampling with glass tubes or syringes, the puncheons were pushed to the open ends and placed on the sediment. While the puncheons remained in place, the glass tubes or syringes were pushed forward into the sediment. After retraction, open ends of glass tubes and syringes were sealed tightly with rubber stoppers for anoxic incubation. Subsequently, incubations with radiotracers were carried out in the closed glass vials.

\subsection{Anaerobic oxidation of methane (AOM)}

On board, radioactive methane $\left({ }^{14} \mathrm{CH}_{4}\right.$ dissolved in water, $15 \mu \mathrm{L}$ injection volume, activity $1-2 \mathrm{kBq}$, specific activity $2.28 \mathrm{GBq} \mathrm{mmol}^{-1}$ ) was injected into replicate push cores at $1 \mathrm{~cm}$ intervals according to the whole-core injection method of Jørgensen (1978). Alternatively, radioactive methane was injected through the rubber stoppers into sediment sampled from GC cores. After tracer injection, the push cores or glass tubes were incubated at in situ temperature $\left(8^{\circ} \mathrm{C}\right)$ for $24 \mathrm{~h}$ in the dark. Subsequently, microbial activity was terminated by sectioning $1 \mathrm{~cm}$ intervals of sediment into $40 \mathrm{~mL}$ glass vials filled with $20 \mathrm{~mL}$ of sodium hydroxide $(2.5 \% \mathrm{w} / \mathrm{w})$. All 
Table 1. Overview of sampled stations at Mound 11 and 12 during cruises SO206, SO173/4, M66/3a, and M54/3a.

\begin{tabular}{lllrrr}
\hline Site & Station & Instrument & Lat. $\left(\mathrm{N}^{\circ}\right)$ & Long. $\left(\mathrm{W}^{\circ}\right)$ & Water depth $(\mathrm{m})$ \\
\hline Mound 11 & SO206-38 & GC & $8^{\circ} 55.36^{\prime}$ & $-84^{\circ} 18.22^{\prime}$ & 1016 \\
Mound 11 & SO206-39 & TV-MUC & $8^{\circ} 55.34^{\prime}$ & $-84^{\circ} 18.23^{\prime}$ & 1005 \\
Mound 11 & SO206-50 & GC & $8^{\circ} 55.33^{\prime}$ & $-84^{\circ} 18.23^{\prime}$ & 1003 \\
Mound 11 & M54-155 & GC & $8^{\circ} 55.36^{\prime}$ & $-84^{\circ} 18.23^{\prime}$ & 1018 \\
Mound 12 & SO206-44 & TV-MUC & $8^{\circ} 55.69^{\prime}$ & $-84^{\circ} 18.79^{\prime}$ & 1007 \\
Mound 12 & SO206-46 & TV-MUC & $8^{\circ} 55.72^{\prime}$ & $-84^{\circ} 18.83^{\prime}$ & 1009 \\
Mound 12 & M54-97-2 & GC & $8^{\circ} 55.90^{\prime}$ & $-84^{\circ} 18.70^{\prime}$ & 1001 \\
Mound 12 & SO173 110-1 & GC & $8^{\circ} 55.74^{\prime}$ & $-84^{\circ} 18.81^{\prime}$ & 1008 \\
Mound 12 & M66-213 & GC & $8^{\circ} 55.85^{\prime}$ & $-84^{\circ} 18.60^{\prime}$ & 980 \\
\hline
\end{tabular}

Table 2. List of carbonate samples from Mound 11 and 12 used for mineralogy and stable isotope analysis of carbonates. Samples from SO173, M66, and M54 were used for ${ }^{87} \mathrm{Sr} /{ }^{86} \mathrm{Sr}$ and $\delta^{13} \mathrm{C}$ analysis $(\mathrm{cmbsf}=$ centimetres below seafloor $)$.

\begin{tabular}{|c|c|c|}
\hline Site & Station & $\begin{array}{r}\text { Depth } \\
\text { (cmbsf) }\end{array}$ \\
\hline Mound 11 & SO206-38 & $172-185$ \\
\hline Mound 11 & SO206-39 & 8 \\
\hline Mound 11 & SO206-39 & $10-12$ \\
\hline Mound 11 & SO206-39 & 11 \\
\hline Mound 11 & SO206-39 & $20-25$ \\
\hline Mound 11 & SO206-39 & $26-30$ \\
\hline Mound 11 & SO206-39, shell & 25 \\
\hline Mound 11 & SO206-39, shell & $26-30$ \\
\hline Mound 11 & M54-155 A & 90 \\
\hline Mound 11 & M54-155 B & 100 \\
\hline Mound 12 & SO206-44 & $5-8$ \\
\hline Mound 12 & SO206-46 & 6-7 \\
\hline Mound 12 & SO173-110-1 & $50-60$ \\
\hline Mound 12 & M66-213 & 0 \\
\hline Mound 12 & M54-97-2 & 353 \\
\hline Mound 12 & M54 97-2 & 353 \\
\hline
\end{tabular}

sediment from a glass tube was transferred into a $40 \mathrm{~mL}$ glass vial with sodium hydroxide. Vials were closed immediately after sediment transfer and shaken vigorously before storage. Controls were first transferred into sodium hydroxide before addition of radiotracer. At GEOMAR, AOM rates were determined after Treude et al. (2005) (gas chromatography, ${ }^{14} \mathrm{CH}_{4}$ combustion, and calculation) and Joye et al. (2004) $\left({ }^{14} \mathrm{CO}_{2}\right.$ trapping).

\subsection{Sulfate reduction $(\mathrm{SR})$ rates}

Sampling, injection, and incubation conditions were identical to that of the AOM samples. The injected radiotracer was radioactive sulfate $\left({ }^{35} \mathrm{SO}_{4}^{2-}\right.$ dissolved in water, $6 \mu \mathrm{L}$ injection volume, activity $200 \mathrm{kBq}$, specific activity $37 \mathrm{TBq} \mathrm{mmol}^{-1}$ ). After $24 \mathrm{~h}$, microbial activity was terminated by sectioning
$1 \mathrm{~cm}$ intervals of sediment into $50 \mathrm{~mL}$ plastic centrifuge vials filled with $20 \mathrm{~mL}$ of zinc acetate $(20 \% \mathrm{w} / \mathrm{w})$. Controls were first transferred into zinc acetate before addition of radiotracer. SR rates were determined using the cold-chromium distillation method by Kallmeyer et al. (2004).

\subsection{X-ray diffraction and isotope analysis of carbonates}

Carbonate samples and bivalve shell fragments were dried at $37^{\circ} \mathrm{C}$ for $12 \mathrm{~h}$ and gently cleaned of sediment remains. The top surface from each carbonate piece was scoured over an area of $\sim 5 \mathrm{~mm} \times 5 \mathrm{~mm}$, after which a small cavity was drilled to yield mineral powder. The powder was analysed for mineralogy using X-ray diffraction (Philips Xray diffractometer PW 1710 with monochromatic $\operatorname{CoK} \alpha$, $40 \mathrm{kV}, 35 \mathrm{~mA}, 0.01^{\circ} \mathrm{s}^{-1}$ ) between 2 and $702 \theta$ (incident angle). The resulting spectra were analysed using the software XPowder ${ }^{\circledR}$ (XPowder, Spain). Quantitative analyses of the spectra were carried out by the reference intensity ratios (RIR) method with a precision of approximately $5 \%$. In order to calculate the molar percentage of $\mathrm{MgCO}_{3}$ of magnesian calcite, the d-104 calcite peak shift was determined after Goldsmith et al. (1961). The standard error was about $\pm 1 \mathrm{~mol} \% \mathrm{MgCO}_{3}$ content according to lab standards (Mavromatis et al., 2012).

From each homogenized carbonate powder sample (see above), an aliquot of $10 \mathrm{mg}$ was separated for carbon $\delta^{13} \mathrm{C}$ and oxygen $\delta^{18} \mathrm{O}$ stable isotope analysis. A fraction (approximately $1 \mathrm{mg}$ ) was dissolved by water-free phosphoric acid at $73{ }^{\circ} \mathrm{C}$ in a "Carbo-Kiel" (Thermo Fischer Scientific Inc.) online carbonate preparation line, and measured for carbon and oxygen stable isotope ratios with a MAT 253 mass spectrometer (Thermo Fischer Inc.). The $\delta^{13} \mathrm{C}$ and $\delta^{18} \mathrm{O}$ values are reported as permil deviation from laboratory standard referred to the V-PDB (Vienna Pee Dee belemnite) scale. The standard deviations given are based on replicate analyses $(n=7)$ of the laboratory standard. External reproducibility was $0.032 \%$ for $\delta^{13} \mathrm{C}$ and $0.054 \%$ for $\delta^{18} \mathrm{O}$ (1- $\sigma$ values).

The $\delta^{18} \mathrm{O}$ values of carbonates are strongly dependent on the temperature at which precipitation occurred and also on the $\delta^{18} \mathrm{O}$ signature of the surrounding liquid phase. In order 


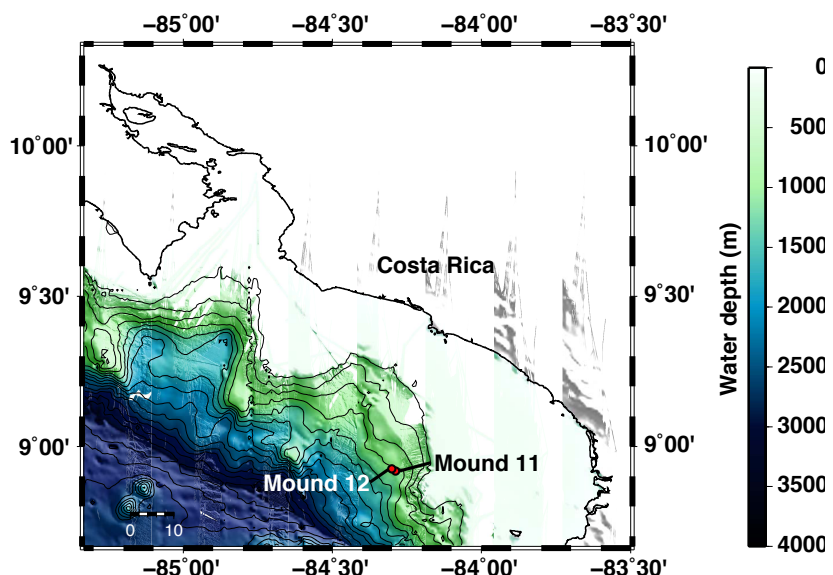

Fig. 1. Bathymetric map of the Pacific continental slope of Costa Rica; locations Mound 11 and Mound 12 are shown.

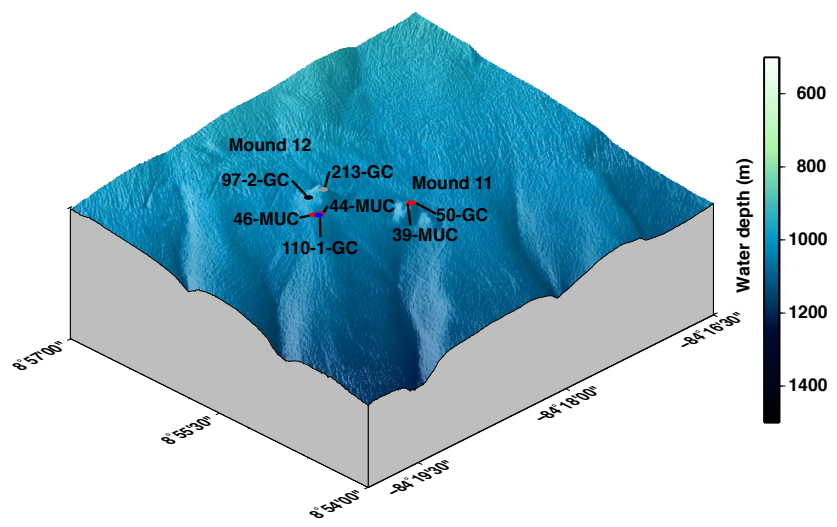

Fig. 2. 3-D relief map of the study area offshore of Costa Rica showing stations at Mound 11 and 12 sampled during expeditions SO206 (red), SO173 (blue), M66 (grey), and M54 (black).

to constrain the hydrological conditions during the precipitation, the equilibrium $\delta^{18} \mathrm{O}$ values for the different carbonate phases with water were calculated for present local seafloor conditions, i.e. a bottom-water temperature of $8^{\circ} \mathrm{C}$ (derived from measurements during $\mathrm{SO} 206)$ and $\delta^{18} \mathrm{O}$ of $+0.2 \%$ (SO206-39 (MUC) bottom water). The equilibrium fractionation factor for ${ }^{18} \mathrm{O}$ between calcite and water was calculated according to Kim and O'Neil (1997):

$1000 \ln \alpha_{\text {calcite- }}$ water $=18.03 \times 10^{3} T^{-1}-32.42$,

with temperature, $T$, in kelvin. The equilibrium $\delta^{18} \mathrm{O}$ value for magnesian calcite and water was calculated by applying a correction factor of $0.06 \%$ for each $\mathrm{mol} \%$ of $\mathrm{MgCO}_{3}$ (Tarutani et al. 1969). The equation of Grossman and $\mathrm{Ku}$ (1986) was used for calculating the $\delta^{18} \mathrm{O}$ equilibrium fractionation factor between aragonite and water:
$T\left({ }^{\circ} \mathrm{C}\right)=21.8-4.69\left(\delta^{18} \mathrm{O}_{\text {aragonite }}-\delta^{18} \mathrm{O}_{\text {water }}\right)$.

The $\delta^{18} \mathrm{O}$ equilibrium fractionation factor between dolomite and water was calculated after Fritz and Smith (1970):

$1000 \ln \alpha_{\text {dolomite- water }}=2.62 \times 10^{6} T^{-2}+2.17$.

In addition, strontium, oxygen, and carbon isotope data of visually selected carbonate-dominated nodule fragments of millimetre size obtained from Mound 11 and 12 during previous cruises (listed in Table 2) are reported in this study. The strontium data were applied as a potential indicator of different fluid sources and their contribution during precipitation.

For strontium isotope analysis, samples were leached with $2.25 \mathrm{~N} \mathrm{HNO}_{3}$ to ensure complete dissolution of carbonate phases. The average concentration of strontium in terrigenous sediments is $240 \mathrm{ppm}$ (Capo et al., 1998), while marine carbonates contain at least by a factor of 5 to 30 more strontium (Dasch, 1969; Bayon et al., 2007). As the samples were carbonate dominated, the contribution of strontium from etched and partially dissolved terrigenous material was considered to be of minor impact.

Strontium isotope ratios were determined by thermal ionization mass spectrometry (TIMS) after chemical separation by cation exchange chromatography using $\mathrm{Sr}$-specific resin (Eichrom). Reported strontium isotope data are normalized to a ${ }^{87} \mathrm{Sr} /{ }^{86} \mathrm{Sr}$ ratio of 0.710248 for NIST 987 according to McArthur et al. (1998). IAPSO standard seawater was measured as a reference for modern seawater ${ }^{87} \mathrm{Sr} /{ }^{86} \mathrm{Sr}$, giving a value of 0.709176 . During the present study, the analytical precision of samples was higher than the external reproducibility of $\pm 1.5 \times 10^{-5}(2 \sigma)$. Only sample SO173 110-1-a (Table 6) showed a lower precision $\left(2.1 \times 10^{-5} 2 \sigma\right)$.

\subsection{Numerical modelling of measured data}

A simple one-dimensional transport-reaction model similar to previously published approaches (Hensen and Wallmann, 2005; Schmidt et al., 2005; Wallmann et al., 2006; Dale et al., 2010) was formulated to simulate the measured porewater profiles of $\mathrm{Cl}^{-}, \mathrm{SO}_{4}^{2-}, \mathrm{CH}_{4}$, total hydrogen sulfide, $\left(\mathrm{TH}_{2} \mathrm{~S}, \sim \mathrm{H}_{2} \mathrm{~S}+\mathrm{HS}^{-}\right), \mathrm{HCO}_{3}^{-}$, and $\mathrm{Ca}^{2+}$ in the three MUC cores and one gravity core (Table 3 ). The model was primarily used to quantify upward flow velocities, benthic fluxes, and rates of $\mathrm{AOM}$ and $\mathrm{CaCO}_{3}$ precipitation. Processes considered include porewater advection and irrigation (non-local exchange), sediment accumulation, and molecular diffusion of dissolved species. Organic matter degradation was not simulated as its rate is assumed to be insignificant compared to methane-related SR and AOM (Karaca et al., 2010; Wallmann et al., 2006). 
Table 3. Summary of model input parameters and boundary conditions used for numerical modelling of biogeochemical processes at Mound 11 and 12 .

\begin{tabular}{|c|c|c|c|c|c|c|}
\hline & $\begin{array}{r}\text { Mound 11, } \\
\text { SO206-39 }\end{array}$ & $\begin{array}{l}\text { Mound 11, } \\
\text { SO206-50 }\end{array}$ & $\begin{array}{r}\text { Mound 12, } \\
\text { SO206-44 }\end{array}$ & $\begin{array}{r}\text { Mound 12, } \\
\text { SO206-46 }\end{array}$ & unit & constraint \\
\hline \multicolumn{7}{|l|}{ Model parameter values } \\
\hline Length core & 35.5 & 290 & 13 & 9 & $\mathrm{~cm}$ & measured \\
\hline Length of simulated sediment column & 100 & 500 & 100 & 100 & $\mathrm{~cm}$ & pre-defined \\
\hline Number of model layers & 200 & 120 & 200 & 200 & - & pre-defined \\
\hline Temperature $(T)$ & 8 & 8 & 8 & 8 & ${ }^{\circ} \mathrm{C}$ & measured \\
\hline Salinity $(S)$ & 35 & 35 & 35 & 35 & PSU & measured \\
\hline Pressure $(P)$ & 101 & 101 & 101 & 101 & bar & measured \\
\hline Porosity at sediment surface $\left(\phi_{\text {top }}\right)$ & 0.84 & 0.65 & 0.76 & 0.82 & 1 & measured \\
\hline Porosity at infinite sediment depth $\left(\phi_{\text {bot }}\right)$ & 0.66 & 0.68 & 0.68 & 0.68 & 1 & fitted \\
\hline Attenuation coefficient for porosity decrease with depth (const) & 0.04 & 0 & 0.12 & 0.16 & $\mathrm{~cm}^{-1}$ & fitted \\
\hline Burial velocity at depth $\left(\omega_{\text {bot }}\right)$ & 0.02 & 0.02 & 0.02 & 0.02 & $\mathrm{~cm} \mathrm{yr}^{-1}$ & pre-defined $*$ \\
\hline Fluid flow at the sediment-water interface ( $\left.v_{\text {top }}\right)$ & 200 & 1.2 & 15 & 15 & $\mathrm{~cm} \mathrm{yr}^{-1}$ & fitted \\
\hline Kinetic constant for the anaerobic oxidation of methane $\left(k_{\mathrm{AOM}}\right)$ & 15000 & 200 & 6400 & 1000 & $\mathrm{mmol}^{-1} \mathrm{~cm}^{3} \mathrm{yr}^{-1}$ & fitted \\
\hline Kinetic constant for $\mathrm{CaCO}_{3}$ precipitation $\left(k_{\mathrm{Ca}}\right)$ & 50000 & 0.85 & 80 & 500 & $\mathrm{yr}^{-1}$ & fitted \\
\hline Kinetic constant for $\mathrm{H}_{2} \mathrm{~S}$ removal from porewater $\left(k_{\mathrm{reS}}\right)$ & 0.01 & 0.0005 & 0 & 0 & $\mathrm{mmol} \mathrm{cm}{ }^{-3} \mathrm{yr}^{-1}$ & fitted \\
\hline Attenuation coefficient for decrease in $\mathrm{H}_{2} \mathrm{~S}$ removal rate (remS) & 0.01 & 0 & 0.00002 & 0 & $\mathrm{~cm}^{-1}$ & fitted \\
\hline Non-local mixing coefficient $\left(\alpha^{\prime}\right)$ & 500 & 1.2 & 50 & 250 & $\mathrm{yr}^{-1}$ & fitted \\
\hline Depth of irrigated layer $\left(x_{\operatorname{mix}}\right)$ & 1 & 20 & 3 & 0 & $\mathrm{~cm}$ & fitted \\
\hline Irrigation parameter $\left(w_{\text {mix }}\right)$ & 1.7 & 30 & 0.8 & 2 & $\mathrm{~cm}$ & fitted \\
\hline \multicolumn{7}{|l|}{ Porewater concentration upper/lower boundary } \\
\hline $\mathrm{BW} \mathrm{SO}_{4}^{2-} / \mathrm{BS} \mathrm{SO}_{4}^{2-}$ & $27 / 0$ & $28.5 / 0$ & $28.5 / 0$ & $28.5 / 0$ & $\mathrm{mM}$ & measured \\
\hline $\mathrm{BW} \mathrm{CH}_{4} / \mathrm{BS} \mathrm{CH}_{4}$ & $0.00001 / 75$ & $0.00001 / 85$ & $0.00001 / 85$ & $0.00001 / 85$ & $\mathrm{mM}$ & measured \\
\hline $\mathrm{BW} \mathrm{Cl}^{-} / \mathrm{BS} \mathrm{Cl}^{-}$ & $548 / 200$ & $550.5 / 10$ & $557.5 / 550$ & $550.5 / 550$ & $\mathrm{mM}$ & measured \\
\hline $\mathrm{BW} \mathrm{HCO}_{3}^{-} / \mathrm{BS} \mathrm{HCO}_{3}^{-}$ & $2.3 / 4.5$ & $4.0 / 0$ & $2.3 / 30$ & $2.3 / 30$ & $\mathrm{mM}$ & calculated \\
\hline $\mathrm{BW} \mathrm{Ca}^{2+} / \mathrm{BS} \mathrm{Ca}^{2+}$ & $10.18 / 9.20$ & $10.5 / 10.0$ & $10.4 / 6.0$ & $10.42 / 8.54$ & $\mathrm{mM}$ & measured \\
\hline BW total sulfide/ BS total sulfide & $0.001 / 0.0$ & $0.001 / 1.0$ & $0.001 / 0.0$ & $0.001 / 0.0$ & $\mu \mathrm{M}$ & measured \\
\hline
\end{tabular}

A partial differential equation based on the classical approach for early diagenesis (Berner, 1980) was used to simulate the steady-state concentrations and fluxes:

$\phi(x) \cdot \frac{\partial C(x)}{\partial t}=\frac{\partial\left(\phi(x) \cdot D_{\mathrm{sed}}(x) \cdot \frac{\partial C(x)}{\partial x}\right)}{\partial x}$

$-\frac{\partial(\phi(x) v(x) C(x))}{\partial x}+\phi(x) \cdot R(x)$

where $C(x)$ is the concentration of dissolved species in pore fluids ( $\mathrm{mmol} \mathrm{l}^{-1}$ ), $t$ is the time (yr), $x$ is the sediment depth $(\mathrm{cm}), \phi(x)$ is the sediment porosity, $D_{\text {sed }}(x)$ is the molecular diffusion coefficient in sediments $\left(\mathrm{cm}^{2} \mathrm{yr}^{-1}\right), v(x)$ is the advection velocity of pore fluid $\left(\mathrm{cm} \mathrm{yr}^{-1}\right)$, and $R(x)$ represents the sum of all reactions considered in the simulated sediment domain.

Due to compaction, sediment porosity decreases with depth and can be approximated by

$\phi(\chi)=\left(\phi_{\mathrm{top}}-\phi_{\mathrm{bot}} \cdot e^{(-\mathrm{const} \cdot x)}+\phi_{\mathrm{bot}}\right.$,

where $\phi_{\text {top }}$ is the porosity at the upper boundary and const $\left(\mathrm{cm}^{-1}\right)$ is the attenuation coefficient for the decrease of porosity with depth.
The velocity of pore fluid advection through sediments consists of a downward component due to burial and compaction and an upward component due to fluid advection from depth:

$v(x)=\frac{\omega_{\mathrm{bot}} \cdot \phi_{\mathrm{bot}}-v_{\mathrm{top}} \cdot \phi_{\mathrm{top}}}{\phi(x)}$,

where $\omega_{\text {bot }}$ is the sedimentation rate at the lower boundary $\left(\mathrm{cm} \mathrm{yr}^{-1}\right), \phi_{\text {bot }}$ is the porosity at the lower boundary, and $v_{\text {top }}\left(\mathrm{cm} \mathrm{yr}^{-1}\right)$ is the upward-directed fluid velocity at the sediment surface.

Temperature-dependent molecular diffusion coefficients of dissolved species were calculated according to Boudreau (1997) and corrected for tortuosity:

$D_{\text {sed }}(x)=\frac{D_{0}}{1-\ln (\phi(x))^{2}}$,

where $D_{0}$ is the molecular diffusion coefficient in seawater at the in situ temperature.

Admixing of bottom water into the upper sediment column is a process which is typically observed in seep environments and has been ascribed to various processes such as density-driven formation of convection cells or irrigation through bubble ebullition (Henry et al., 1996; Haeckel et al., 2007; Chuang et al., 2013). In general, these processes can be 
simulated by including a non-local mixing term (Boudreau and Marinelli, 1994; Schmidt et al., 2005):

$R_{\text {mix }}(x)=\alpha(x) \cdot(C(x)-C(0))$,

$\alpha^{\prime}(x)=\frac{\alpha^{\prime}}{\left(1+e^{\left.\left(x-x_{\text {mix }}\right) / w_{\text {mix }}\right)}\right.}$,

where $\alpha^{\prime}(x)\left(\mathrm{yr}^{-1}\right)$ is the depth-dependent irrigation coefficient, $\alpha^{\prime}\left(\mathrm{yr}^{-1}\right)$ is a site-specific irrigation coefficient $\left(\mathrm{yr}^{-1}\right)$, $(C(x)-C(0))$ is the difference in solute concentration between seawater and sediment, $x_{\text {mix }}(\mathrm{cm})$ is the depth of the mixed layer, and $w_{\text {mix }}(\mathrm{cm})$ represents the thickness of the transition layer between irrigated and non-irrigated sediment layers.

Methane is oxidized with sulfate during AOM, resulting in the production of hydrogen sulfide and bicarbonate:

$\mathrm{CH}_{4}+\mathrm{SO}_{4}^{2-} \rightarrow \mathrm{HCO}_{3}^{-}+\mathrm{HS}^{-}+\mathrm{H}_{2} \mathrm{O}$.

The rate of $\mathrm{AOM}\left(R_{\mathrm{AOM}}, \mathrm{mmol} \mathrm{cm}{ }^{-3} \mathrm{yr}^{-1}\right)$ was calculated using a bimolecular rate law:

$R_{\mathrm{AOM}}(x)=k_{\mathrm{AOM}} \cdot\left(\left(\mathrm{SO}_{4}^{2-}\right)\left(\mathrm{CH}_{4}\right)\right)$,

where $k_{\mathrm{AOM}}$ is a kinetic constant for the anaerobic oxidation of methane (in $\mathrm{mmol}^{-1} \mathrm{~cm}^{3} \mathrm{yr}^{-1}$ ).

In order to produce fits to porewater profiles of dissolved hydrogen sulfide, precipitation of iron sulfides is assumed using Eq. (13) as suggested by Wallmann et al. (2008):

$\mathrm{H}_{2} \mathrm{~S}+{ }^{2} / 5 \mathrm{Fe}_{2} \mathrm{O}_{3} \rightarrow{ }^{2} /{ }_{5} \mathrm{FeS}_{2}+{ }^{1} / 5 \mathrm{FeS}+1 /{ }_{5} \mathrm{FeO}+\mathrm{H}_{2} \mathrm{O}$.

The general depth-dependent function of sulfide removal from pore fluid $\left(R_{\text {Sprec }}(x)\right)$ is defined as

$R_{\mathrm{Sprec}}(x)=\frac{\left(\mathrm{H}_{2} \mathrm{~S}\right)}{K_{\mathrm{SP}}+\left(\mathrm{H}_{2} \mathrm{~S}\right)} \cdot k_{\mathrm{reS}} \cdot e^{(-\mathrm{remS} \cdot x)}$,

where $K_{\mathrm{SP}}$ is the Michaelis-Menten constant for sulfide removal in $\mathrm{mmol} \mathrm{cm} \mathrm{cm}^{-3}, k_{\mathrm{reS}}$ is a kinetic constant for total sulfide removal from pore fluids in $\mathrm{mmol} \mathrm{cm}^{-3} \mathrm{yr}^{-1}$, and remS is the attenuation coefficient for the decrease in sulfide removal rate with depth in $\mathrm{cm}^{-1}$.

Rates of $\mathrm{CaCO}_{3}$ precipitation were derived by fitting the model curve to the porewater $\mathrm{Ca}^{2+}$ profile:

$R_{\mathrm{Ca}}(x)=k_{\mathrm{Ca}} \cdot\left(\mathrm{Ca}_{\text {meas }}(x)-\mathrm{Ca}_{\text {mod }}(x)\right)$,

An analytical function was fit through the data $\left(\mathrm{Ca}_{\text {meas }}(x)\right)$. The rate of $\mathrm{CaCO}_{3}$ precipitation is thus a function of the concentration difference between $\mathrm{Ca}^{2+}$ calculated in the model during each depth interval and time step $\left(\mathrm{Ca}_{\bmod }(x)\right)$ and the measured $\mathrm{Ca}^{2+}\left(\mathrm{Ca}_{\text {meas }}(x)\right)$. Precipitation rates were adjusted by varying the rate constant $k_{\mathrm{Ca}}$ (in $\mathrm{yr}^{-1}$ ). Precipitation of $\mathrm{CaCO}_{3}$ consumes two moles of bicarbonate per mole of $\mathrm{Ca}^{2+}$ :

$\mathrm{Ca}^{2+}+2 \mathrm{HCO}_{3}^{-} \rightarrow \mathrm{CaCO}_{3}+\mathrm{CO}_{2}+\mathrm{H}_{2} \mathrm{O}$.
The loss of $\mathrm{HCO}_{3}^{-}$during precipitation of $\mathrm{CaCO}_{3}$ and the production of $\mathrm{HCO}_{3}^{-}$and $\mathrm{HS}^{-}$during AOM strongly affect porewater total alkalinity (TA). Neglecting minor porewater constituents such as $\mathrm{B}(\mathrm{OH})_{4}^{-}$, TA can be defined as

$\mathrm{TA}=\mathrm{HCO}_{3}^{-}+2 \mathrm{CO}_{3}^{2-}+\mathrm{HS}^{-}$.

At prevailing $\mathrm{pH}$ values between 7 and $8, \mathrm{HCO}_{3}^{-}$contributes more than $90 \%$ to the carbonate alkalinity and $\mathrm{HS}^{-}$dominates $\mathrm{TH}_{2} \mathrm{~S}$, and as such a simplified alkalinity calculation can be performed considering only these two major species in our modelling approach:

$\mathrm{TA}=\mathrm{HCO}_{3}^{-}+\mathrm{HS}^{-}$.

This approach is not meant to substitute a full representation of the carbonate system. Instead, the comparison between measured and modelled alkalinity and hydrogen sulfide profiles provides a constraint on chosen $\mathrm{AOM}$ and $\mathrm{CaCO}_{3}$ precipitation rates.

At the upper and lower boundary of the model column, constant concentrations of dissolved species were prescribed (Dirichlet boundary conditions). The individual bottomwater concentrations of chemical species were defined as upper boundary conditions $(0 \mathrm{~cm})$ for each of the four modelled cores. Chemical species concentrations at the base of the cores served as lower boundary conditions. The upper and lower boundary conditions as well as other model parameters are summarized in Table 3.

Reliable measurements of dissolved methane were not available since most of the dissolved methane is typically lost during core retrieval (e.g. Hensen et al., 2007). Because all modelled cores indicate methane saturation at some depth below the zone of sulfate penetration, methane concentrations at the lower boundary were defined by calculating the (temperature-, pressure-, and chlorinity-dependent) solubility with respect to gas hydrate stability (Tishchenko et al., 2005) for each core separately.

Central finite differences were applied to approximate the spatial derivatives of the partial differential equations (PDEs). The NDSolve object of Mathematica ${ }^{\circledR}$ version 7.0 (method-of-lines technique) was used to solve the resulting systems of ordinary differential equations (ODEs).

\section{Results}

\subsection{Porewater chemistry and microbial turnover rates}

Biogeochemical profiles obtained at Mound 11, stations SO206-39 (MUC) and SO206-50 (GC) respectively (Fig. 3) revealed considerable differences regarding the vertical position of the sulfate-methane transition zone (SMT) and the location of peak microbial turnover rates of methane and sulfate (Fig. 3a, e). The sediment core from SO20639 showed a strong decline of sulfate from a surface 
concentration of $27.4 \mathrm{mmol} \mathrm{SO}{ }_{4}^{2-} \mathrm{L}^{-1}$ to $<0.5 \mathrm{mmol} \mathrm{L}^{-1}$ within the first $6 \mathrm{~cm}$ below seafloor (cmbsf). Methane concentration increased from $2 \mathrm{mmol} \mathrm{CH}_{4} \mathrm{~L}^{-1}$ at $21 \mathrm{cmbsf}$ to $17.9 \mathrm{mmol} \mathrm{CH}_{4} \mathrm{~L}^{-1}$ at $7.5 \mathrm{cmbsf}$. Towards the surface, values further declined to $0.6 \mathrm{mmolCH}_{4} \mathrm{~L}^{-1}$. The SMT was located at $\sim 5 \mathrm{cmbsf}$. Sulfate concentration at station SO206-50 (GC) decreased from a surface concentration of $27.5 \mathrm{mmol} \mathrm{SO}_{4}^{2-} \mathrm{L}^{-1}$ to $<0.5 \mathrm{mmol} \mathrm{SO}_{4}^{2-} \mathrm{L}^{-1}$ at $150.5 \mathrm{cmbsf}$. Methane declined from $5.1 \mathrm{mmol} \mathrm{CH}_{4} \mathrm{~L}^{-1}$ at the bottom of the core $(290 \mathrm{cmbsf})$ to $1.9 \mathrm{mmol} \mathrm{CH}_{4} \mathrm{~L}^{-1}$ at $210 \mathrm{cmbsf}$. At a sediment depth of $190 \mathrm{cmbsf}$ methane concentration steeply increased to $20.9 \mathrm{mmol} \mathrm{CH}_{4} \mathrm{~L}^{-1}$, followed by a sharp decline to a surface concentration of $0.06 \mathrm{mmol} \mathrm{CH}_{4} \mathrm{~L}^{-1}$. The SMT at station SO206-50 was located at $\sim 125 \mathrm{cmbsf}$, i.e. considerably deeper compared to SO206-39.

At Mound 11, AOM and SR rates from SO206-39 showed peak values of $4.4 \mu \mathrm{mol} \mathrm{CH}_{4} \mathrm{~cm}^{-3} \mathrm{~d}^{-1}$ and $8.1 \mu \mathrm{mol} \mathrm{SO}_{4}^{2-} \mathrm{cm}^{-3} \mathrm{~d}^{-1}$, respectively, between 2 and $5 \mathrm{cmbsf}$ (Fig. 3b, c). Corresponding integrated average areal rates $(0-10 \mathrm{~cm})$ were $140.71( \pm 40.84 \mathrm{SD}, n=3)$ $\mathrm{mmol} \mathrm{CH}_{4} \mathrm{~m}^{-2} \mathrm{~d}^{-1}$ for $\mathrm{AOM}$ and $117.25( \pm 82.06 \mathrm{SD}$, $n=3) \quad \mathrm{mmol} \mathrm{SO}_{4}^{2-} \mathrm{m}^{-2} \mathrm{~d}^{-1}$ for $\mathrm{SR}$ (Table 4). At SO206-50, maximum rates for AOM and SR reached $0.01 \mu \mathrm{mol} \mathrm{CH} 4 \mathrm{~cm}^{-3} \mathrm{~d}^{-1}$ and $0.017 \mu \mathrm{mol} \mathrm{SO}{ }_{4}^{2-} \mathrm{cm}^{-3} \mathrm{~d}^{-1}$, respectively, at $65 \mathrm{cmbsf}$ (Fig. 3f, g). Corresponding areal rates, integrated over the sampled core length $(290 \mathrm{~cm})$, yielded average values of $4.76( \pm 2.21 \mathrm{SD}, n=3)$ $\mathrm{mmol} \mathrm{CH}_{4} \mathrm{~m}^{-2} \mathrm{~d}^{-1}$ for AOM and $45.48( \pm 53.67 \mathrm{SD}, n=2)$ $\mathrm{mmol} \mathrm{SO}_{4}^{2-} \mathrm{m}^{-2} \mathrm{~d}^{-1}$ for SR. Despite the differences in AOM and SR rates of stations SO206-50 and SO206-39, maximum sulfide $\left(2.3\right.$ and $\left.4.4 \mathrm{mmol} \mathrm{L}^{-1}\right)$ and total alkalinity $\left(2.1\right.$ and $\left.4.2 \mathrm{meq}^{-1}\right)$ levels were of the same order of magnitude in both cores (Fig. 3d, h). In contrast to SO206-50 the curvatures of sulfide and TA at SO206-39 showed a downward concavity below the SMT.

At Mound 12, the sulfate and methane concentration profiles differed between the two stations SO206-44 (MUC) and SO206-46 (MUC) (Fig. 4a, e). At station SO206-44, sulfate decreased gradually from surface concentrations of 28.4 to $4.2 \mathrm{mmol} \mathrm{SO}_{4}^{2-} \mathrm{L}^{-1}$ between 5 and $7 \mathrm{cmbsf}$. Below this depth, sulfate concentration declined to $1.4 \mathrm{mmol} \mathrm{SO}_{4}^{2-} \mathrm{L}^{-1}$ at the core bottom $(13 \mathrm{cmbsf})$. Methane concentrations in SO206-44 sediment varied considerably over the entire core length of $20 \mathrm{~cm}$. At the surface, methane concentration was $3.5 \mathrm{mmol} \mathrm{CH}_{4} \mathrm{~L}^{-1}$, followed by an increase to $\sim 14 \mathrm{mmol} \mathrm{CH}_{4}^{\mathrm{L}-1}$ between 2.5 and $6.5 \mathrm{cmbsf}$. Below this depth, methane concentration varied between 1 and $12 \mathrm{mmol} \mathrm{L}^{-1}$. Due to the presence of massive carbonate layers in the sediment, core liner penetration at station SO206-46 was limited to $12-15 \mathrm{cmbsf}$. Here, sulfate declined from surface concentrations of $28.3 \mathrm{mmol} \mathrm{SO}_{4}^{2-} \mathrm{L}^{-1}$ to $11.5 \mathrm{mmol} \mathrm{SO}_{4}^{2-} \mathrm{L}^{-1}$ at $9 \mathrm{cmbsf}$. Methane increased from 1.3 to $19.1 \mathrm{mmol} \mathrm{CH}_{4} \mathrm{~L}^{-1}$ between 11 and $9 \mathrm{cmbsf}$, declin- ing steeply to $<0.2 \mathrm{mmol} \mathrm{CH}_{4} \mathrm{~L}^{-1}$ towards the sediment surface.

Highest rates for AOM and SR at Mound 12 were measured between 2 and $5 \mathrm{cmbsf}$ at both stations. At station SO206-44, peak values of $0.58 \mu \mathrm{mol} \mathrm{CH}_{4} \mathrm{~cm}^{-3} \mathrm{~d}^{-1}$ and $0.52 \mu \mathrm{mol} \mathrm{SO} \mathrm{S}_{4}^{2-} \mathrm{cm}^{-3} \mathrm{~d}^{-1}$ were measured (Fig. $4 \mathrm{~b}, \mathrm{c}$ ). Integrated average areal rates of the top $10 \mathrm{~cm}$ yielded $22.37( \pm 0.85 \mathrm{SD}, n=3) \mathrm{mmolCH}_{4} \mathrm{~m}^{-2} \mathrm{~d}^{-1}$ and 23.99 $( \pm 5.79 \mathrm{SD}, n=3) \mathrm{mmol} \mathrm{SO}_{4}^{2-} \mathrm{m}^{-2} \mathrm{~d}^{-1}$ for AOM and SR, respectively (Table 4). At station SO206-46, microbial rates were slightly higher, reaching maximum values of $0.65 \mu \mathrm{mol} \mathrm{CH} \mathrm{cm}^{-3} \mathrm{~d}^{-1}(\mathrm{AOM})$ and $2.30 \mu \mathrm{mol} \mathrm{cm}{ }^{-3} \mathrm{~d}^{-1}$ (SR) (Fig. 4f, g). Corresponding average areal rates were $10.68( \pm 3.53 \mathrm{SD}, n=3)$ for $\mathrm{AOM}$ and $64.97( \pm 6.79 \mathrm{SD}$, $n=3$ ) for SR.

\subsection{Numerical modelling results}

The advective fluid flow velocity and AOM and calcium carbonate precipitation rates were determined by fitting the model to the porewater data. Parameter values and boundary conditions used for simulations (Table 3) yielded good fits to the measured porewater profiles (see supplementary information, Figs. 1S-4S). Considerable deviations between model results and porewater data occurred only for methane and hydrogen sulfide profiles, as measured concentrations were lower than simulated values. This discrepancy is caused by the loss of methane and hydrogen sulfide due to outgassing during core retrieval and has been reported before (e.g. Karaca et al., 2010; Hensen et al., 2007).

The depth-integrated AOM rates differed considerably between the two cores obtained at Mound 11 (SO206-39 (MUC) and SO206-50 (GC)) (Table 4). For station SO20639 an AOM rate of $143.69 \mathrm{mmol} \mathrm{CH}_{4} \mathrm{~m}^{-2} \mathrm{~d}^{-1}$ (integrated from 0 to $100 \mathrm{~cm}$ sediment depth) was calculated. In contrast, at station SO206-50 the modelled AOM rate (integrated from 0 to $500 \mathrm{~cm}$ sediment depth) was two orders of magnitude lower $\left(1.62 \mathrm{mmol} \mathrm{CH}_{4} \mathrm{~m}^{-2} \mathrm{~d}^{-1}\right)$. The two stations at Mound 12 (SO206-44 (MUC), SO206-46 (MUC)) showed modelled AOM rates (each integrated from 0 to $100 \mathrm{~cm}$ sediment depth) of 22.23 and $16.16 \mathrm{mmol} \mathrm{CH}_{4} \mathrm{~m}^{-2} \mathrm{~d}^{-1}$, respectively. Between stations SO206-39 and SO206-50 (Mound 11) depth-integrated calcium carbonate precipitation rates varied between 6.52 and $0.61 \mathrm{mmol} \mathrm{CaCO}_{3} \mathrm{~m}^{-2} \mathrm{~d}^{-1}$, respectively, while the two stations from Mound 12 showed values of 2.35 (SO206-44) and $1.53 \mathrm{mmol} \mathrm{Ca}^{2+} \mathrm{m}^{-2} \mathrm{~d}^{-1}$ (SO20646).

According to model results, considerable differences of sediment-water column total fluxes of the dissolved chemical species occurred between the two mounds (Table 4). Due to the $1: 1$ stoichiometry of methane and sulfate consumption during $\mathrm{AOM}$, the total influx of sulfate from the water column into the sediment was in accordance with the depthintegrated AOM rates at the four stations with highest sulfate fluxes at station SO206-39 (Mound 11) and SO206-44 

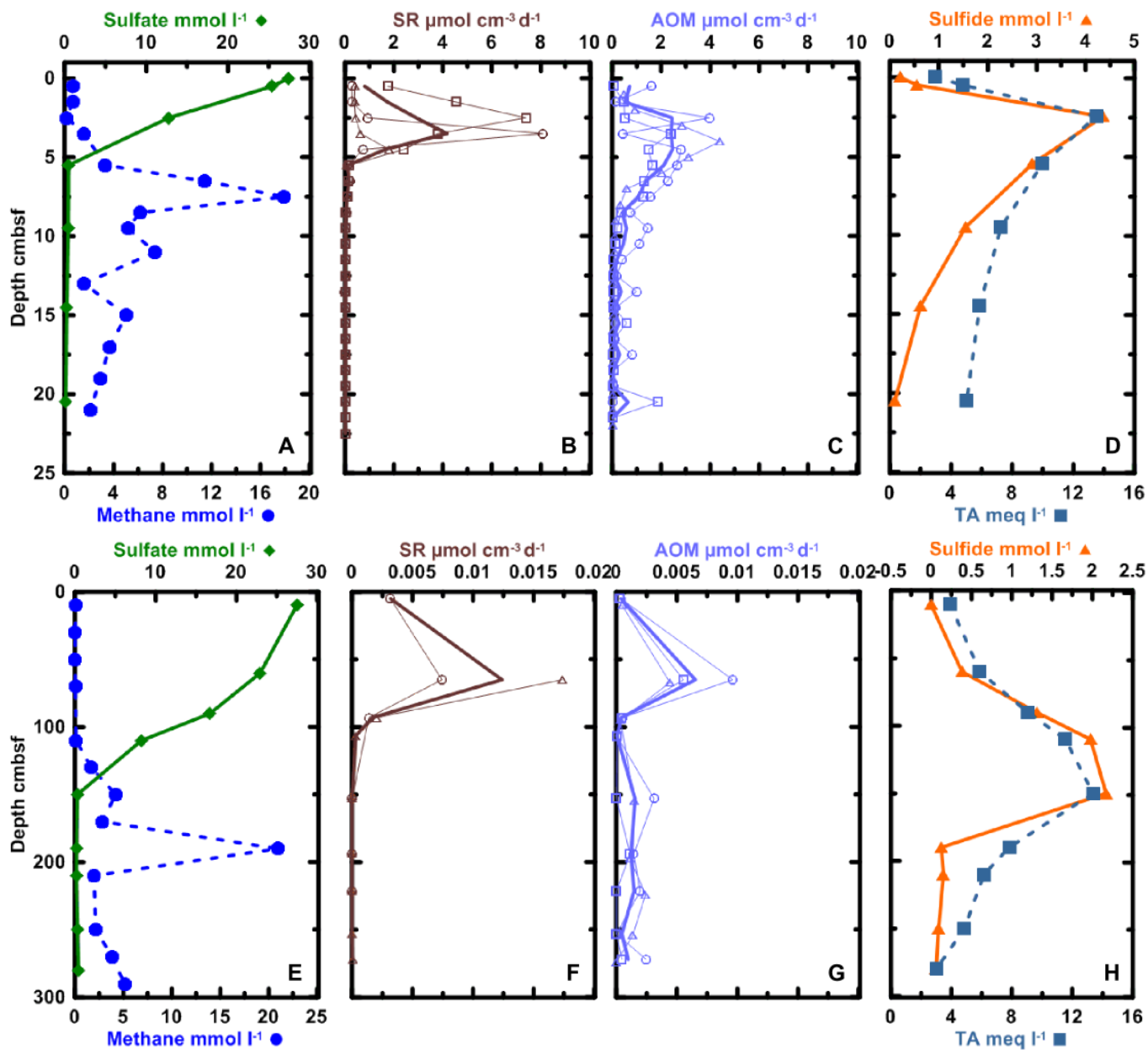

Sulfide $\mathrm{mmol} \mathrm{I}^{-1} \mathrm{~A}$

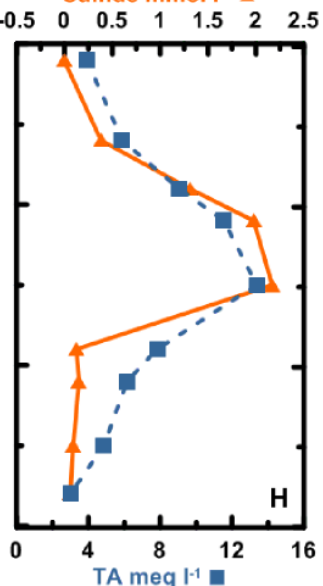

Fig. 3. Mound 11 porewater profiles for sulfate, methane, sulfide, and total alkalinity (TA) as well as rates of sulfate reduction (SR) and anaerobic oxidation of methane (AOM). (A-D): SO206-39 (MUC) (covered by sulfur bacteria mat); (E-H): SO206-50 (GC). For SR and AOM profiles of individual replicates (fine lines with symbols) average profiles (bold lines without symbols) are given. Note the difference in depth (cmbsf) between station SO206-50 (GC) and stations SO206-39, 44, and 46 (MUC).

Table 4. Ex situ determined rates of anaerobic oxidation of methane (AOM) and sulfate reduction (SR) obtained from SO206 MUC sediment cores, in comparison with previous studies. Modelled AOM rates and benthic fluxes are also presented. All rates are expressed in mmol $\mathrm{m}^{-2}$ $\mathrm{d}^{-1}$. Standard deviations (SD) are given.

\begin{tabular}{|c|c|c|c|c|c|c|c|c|c|c|c|}
\hline Site & Station & AOM & SR & $\begin{array}{l}\text { Depth of } \\
\text { integration } \\
(\mathrm{cm})\end{array}$ & $\mathrm{AOM}$ & $\begin{array}{l}\text { Precipitation } \\
\qquad \mathrm{CaCO} 3\end{array}$ & $\mathrm{SO}_{4}^{2-*}$ & $\mathrm{CH}_{4} *$ & $\mathrm{HCO}_{\mathbf{3}}^{-} *$ & $\mathrm{Ca}^{2+*}$ & $\begin{array}{l}\text { Simulated } \\
\text { core } \\
\text { length }(\mathrm{cm})\end{array}$ \\
\hline \multicolumn{5}{|c|}{ measured } & \multicolumn{7}{|c|}{ modelled } \\
\hline Mound 11 & SO206-39 & $140.71( \pm 40.84 \mathrm{SD})$ & $117.25( \pm 82.06 \mathrm{SD})$ & $0-10$ & 143.69 & 6.52 & 143.82 & -201.63 & -151.43 & -35.82 & 100 \\
\hline Mound 11 & SO206-50 & $4.76( \pm 2.21 \mathrm{SD})$ & $45.48( \pm 53.67 \mathrm{SD})$ & $0-270$ & 1.62 & 0.61 & 1.62 & -0.30 & -0.40 & 0.40 & 500 \\
\hline Mound 12 & SO206-44 & $22.37( \pm 0.85 \mathrm{SD})$ & $23.99( \pm 5.79 \mathrm{SD})$ & $0-10$ & 22.23 & 2.35 & 22.24 & -4.28 & -26.89 & 0.48 & 100 \\
\hline Mound 12 & SO206-46 & $10.68( \pm 3.53 \mathrm{SD})$ & $64.97( \pm 6.79 \mathrm{SD})$ & $0-10$ & 16.16 & 1.53 & 16.16 & -12.45 & -23.21 & -1.35 & 100 \\
\hline Mound $12^{1}$ & & 16.11 & & $0-10$ & & & & & & & \\
\hline Mound 11 modelled $^{2}$ & & 9.64 & & $0-27.5$ & & & & & & & \\
\hline Hydrate Ridge ${ }^{3}$ & & $99.00( \pm 102.00 \mathrm{SD})$ & $65.00( \pm 58.00 \mathrm{SD})$ & $0-10$ & & & & & & & \\
\hline Håkon Mosby 4 & & $19.45( \pm 5.48 \mathrm{SD})$ & & $0-10$ & & & & & & & \\
\hline
\end{tabular}

${ }^{1}$ Linke et al. (2000), ${ }^{2}$ Karaca et al. (2010), ${ }^{3}$ Treude et al. (2003), ${ }^{4}$ Niemann et al. (2006). ${ }^{*}$ Total benthic flux; negative values indicate upward flux from sediment into the water column, while positive values represent downward flux from the water column into the sediment. 

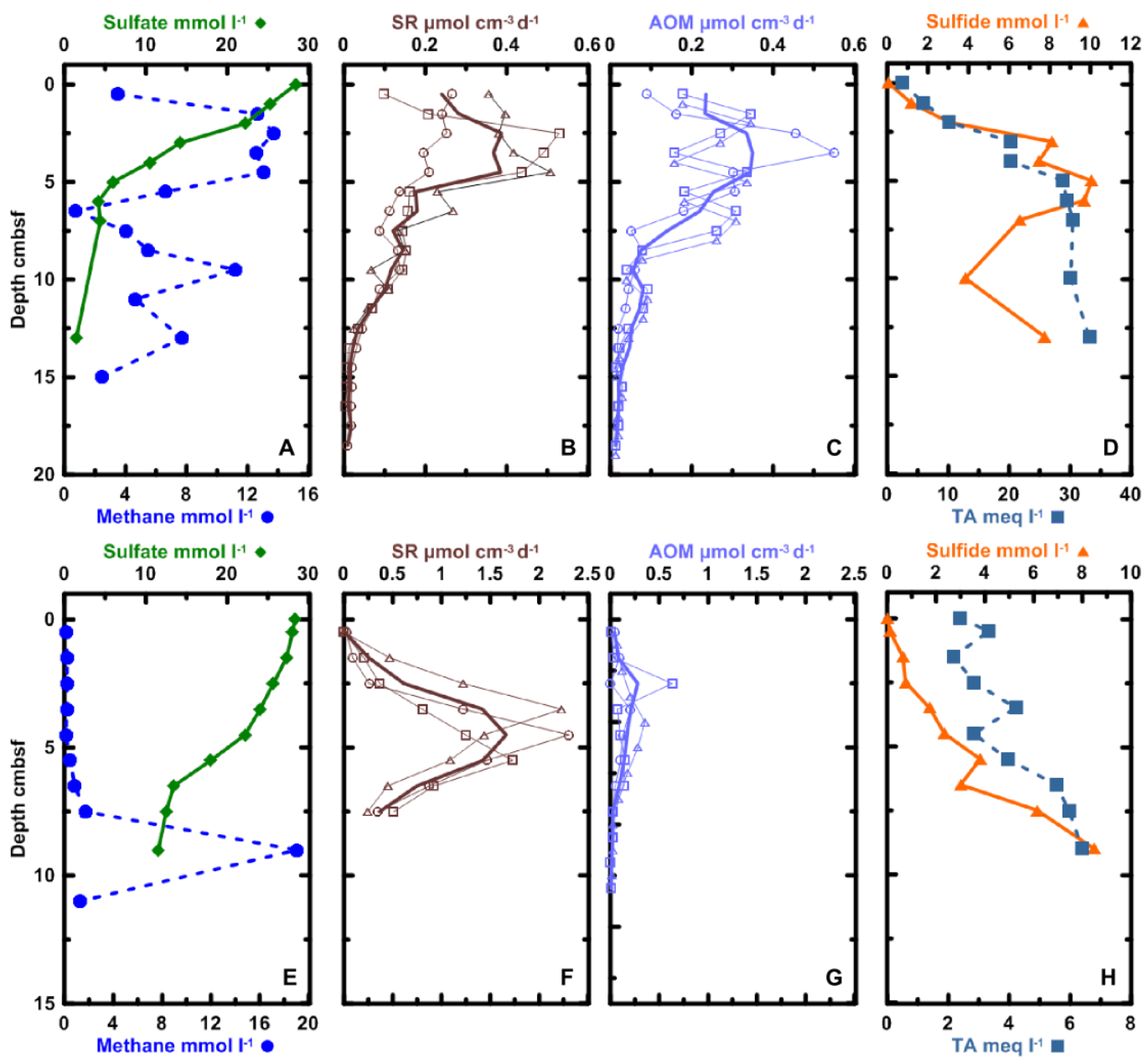

Fig. 4. Mound 12 porewater profiles for sulfate, methane, sulfide, and total alkalinity (TA) as well as sediment rates of sulfate reduction (SR) and anaerobic oxidation of methane (AOM). (A-D): SO206-44 (MUC) (covered by sulfur bacteria mat); (E-H): SO206-46 (MUC) cores (covered by bacterial mat). For SR and AOM profiles of individual replicates (fine lines with symbols), average profiles (bold lines without symbols) are given.

(Mound 12) of 143.82 and $22.24 \mathrm{mmol} \mathrm{SO}_{4}^{2-} \mathrm{m}^{-2} \mathrm{~d}^{-1}$, respectively (Table 4). The calculated methane flux yielded negative values for all stations, indicating a flux from the sediment to the water column. The two stations at Mound 11 showed contrasting values for the absolute methane flux, ranging from 201.63 (SO206-39) to $0.30 \mathrm{mmol} \mathrm{CH}_{4} \mathrm{~m}^{-2} \mathrm{~d}^{-1}$ (SO206-50). Furthermore, the two stations at Mound 12 largely differed in upward methane flux, showing values of 4.28 and $12.45 \mathrm{mmol} \mathrm{CH}_{4} \mathrm{~m}^{-2} \mathrm{~d}^{-1}$, respectively. Modelled total flux of dissolved inorganic carbon - taking into account methane advection rate, $\mathrm{AOM}$ rate, and carbonate precipitation rate - showed bicarbonate $\left(\mathrm{HCO}_{3}^{-}\right)$export from the sediment into the water column at both mounds (Table 4). In accordance to fluid flow and AOM rate, highest bicarbonate flux was found at station SO206-39 (Mound $11,151.43 \mathrm{mmol} \mathrm{C} \mathrm{m}^{-2} \mathrm{~d}^{-1}$ ), while the corresponding flux rate at the neighbouring station SO206-50 was considerably lower $\left(0.40 \mathrm{mmol} \mathrm{HCO}_{3}^{-} \mathrm{m}^{-2} \mathrm{~d}^{-1}\right)$. At the two stations at
Mound 12, total upward bicarbonate flux ranged between 26.89 (SO206-44) and $23.21 \mathrm{mmol} \mathrm{C} \mathrm{m}^{-2} \mathrm{~d}^{-1}$ (SO206-46). Modelled flux rates of calcium showed an upward flux into the water column of 35.82 and $1.35 \mathrm{mmol} \mathrm{Ca}^{2+} \mathrm{m}^{-2} \mathrm{~d}^{-1}$ at stations SO206-39 (Mound 11) and SO1206-46 (Mound 12), respectively. In contrast, stations SO206-50 (Mound 11) and SO206-44 (Mound 12) were characterized by downward calcium fluxes of 0.40 and $0.48 \mathrm{mmol} \mathrm{Ca}^{2+} \mathrm{m}^{-2} \mathrm{~d}^{-1}$, respectively.

\subsection{Carbonate mineralogy and isotopic composition}

The carbonate nodules obtained during the SO206 cruise were composed of a matrix consisting of carbonate-cemented sediment with carbonate contents varying between 52 and $61 \mathrm{wt} \%$. Encountered carbonate shapes varied from elongated structures, some of which exceeded $12 \mathrm{~cm}$ in length, to roundish nodules of $<1$ to $4 \mathrm{~cm}$ diameter. The two shell 


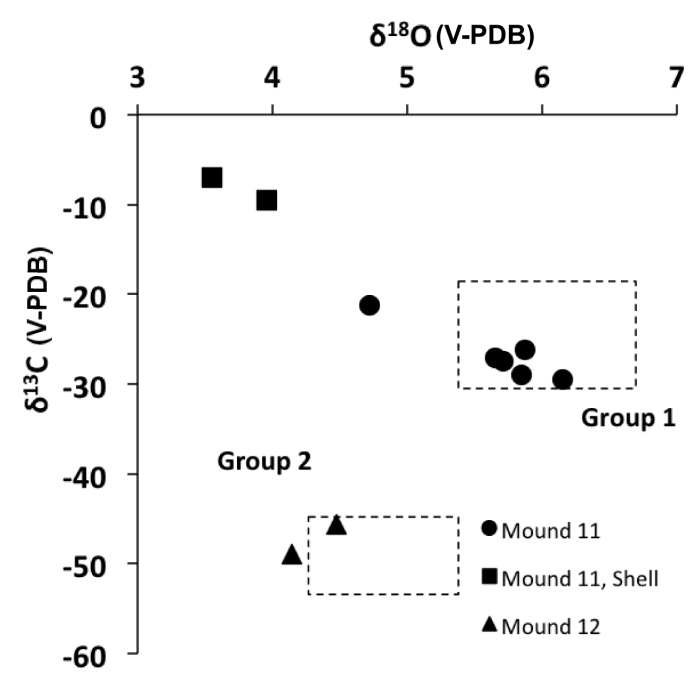

Fig. 5. $\delta^{13} \mathrm{C}$ vs. $\delta^{18} \mathrm{O}$ plot of carbonate material sampled from various locations during SO206 (solid symbols). The grouping was based on isotopic, petrographic, mineralogical, and morphological similarities according to Han et al. (2004). All values refer to the V-PDB scale.

fragments showed carbonate contents of 17 and $31 \mathrm{wt} \%$. The mineralogy of the carbonate nodules from Mound 11 was largely dominated by magnesian calcite, representing 42 to $49 \mathrm{wt} \%$ of the total sample mass, and aragonite (10$13 \mathrm{wt} \%$ of the total sample mass) (Table 5). In one sample at station SO206-39, magnesian calcite occurred together with dolomite. Another Mound 11 sample showed aragonite as the sole carbonate mineral present. In contrast to the carbonate nodules, the two shell fragments most likely belonging to the vesicomyid family were mainly characterized by aragonite and calcite. Carbonate samples excluding the shell samples from Mound 11 were characterized by $\delta^{13} \mathrm{C}$ values ranging from -29.56 to $-14.14 \%$ o $( \pm 0.03 \mathrm{SD})$ (Table 5, Table 6, Fig. 5). Corresponding $\delta^{18} \mathrm{O}$ values varied between 3.18 and $6.15 \%$ ( $( \pm 0.05 \mathrm{SD})$. Isotopic signatures of the two bivalve shell fragments deviated from the authigenic carbonate samples, with $\delta^{18} \mathrm{O}$ being lower (3.55$3.96 \%)( \pm 0.05 \mathrm{SD})$ and $\delta^{13} \mathrm{C}$ values being considerably higher $(-9.61$ to $-6.98 \%$ ) ( $\pm 0.03 \mathrm{SD})$. The two samples from Mound 11 collected during cruise M54 were characterized by varying contents of aragonite and calcite (Table 6 ). In addition, the carbonate-dominated leachates $\left(2.25 \mathrm{~N} \mathrm{HNO}_{3}\right)$ of these samples showed ${ }^{87} \mathrm{Sr} /{ }^{86} \mathrm{Sr}$ ratios $(0.708829$ and 0.709049 ), which were considerably lower than for modern seawater (Table 6).

The two carbonate samples from Mound 12, obtained during SO206, also consisted mainly of magnesian calcite (Table 5). In comparison to Mound 11, the mass of magnesian calcite was smaller, ranging from 33 to $39 \mathrm{wt} \%$. The two samples also differed amongst each other; one contained magnesian calcite and calcite, the other magnesian calcite and aragonite. In contrast, Mound 12 samples from cruises M54, M66, and SO173 were largely dominated by aragonite (Table 6). The carbon and oxygen isotopic signatures of carbonate samples obtained from Mound 12 were in general more negative than at Mound 11. Values for $\delta^{13} \mathrm{C}$ ranged from -48.98 to $-39.53 \%$ ( $( \pm 0.03 \mathrm{SD}$ ) (Tables 5 and 6$), \delta^{18} \mathrm{O}$ ranged between 3.09 and $4.48 \%$ ( $( \pm 0.05 \mathrm{SD})$. In contrast to Mound 11, the carbonate samples collected from Mound 12 generally showed higher ${ }^{87} \mathrm{Sr} /{ }^{86} \mathrm{Sr}$ ratios $(0.709088$ to 0.709167$)$, ranging close to the value for modern seawater (0.709176) (Table 6). The composition of magnesian calcite was rather homogeneous in all samples from the two mounds, with a $\mathrm{MgCO}_{3}$ content ranging between 12 and $16 \mathrm{~mol} \%$. The results for mineralogy and isotopic composition of sampled carbonates are compiled in Tables 5 and 6.

\section{Discussion}

In the present study, considerable differences of microbial AOM and SR activity as well as in $\delta^{18} \mathrm{O}, \delta{ }^{13} \mathrm{C}$, and ${ }^{87} \mathrm{Sr} /{ }^{86} \mathrm{Sr}$ isotopic signatures of carbonates from surface sediment samples of the two neighbouring mounds are indicative of different fluid contributions. In the following sections the differences in microbial activity and carbonate isotopic signatures between Mound 11 and 12 will be discussed.

\subsection{Microbial activity}

Measured areal AOM and SR rates obtained from Mound 11 were up to one order of magnitude higher compared to Mound 12, and were in the same order of rates reported for high-advective cold-seep systems such as Hydrate Ridge (Treude et al., 2003) and Håkon Mosby Mud Volcano (Niemann et al., 2006) (Table 4). To our knowledge, areal measured AOM rates of Mound 11 (SO206-39) exceed values that have been published for marine cold-seep locations so far (e.g. Treude et al., 2003; Joye et al., 2004; Krüger et al., 2005). AOM and SR rates at the Mound 11 station SO206-50 were considerably lower than at SO206-39, illustrating the strong spatial heterogeneity in fluid flow often encountered at seep locations.

The observed difference in AOM and SR rates between the two mounds might be due to different advective transport velocities of methane charged fluid. Previous reactivetransport modelling (Mound 11) (Karaca et al., 2010) and benthic flux chamber experiments (Mound 12) (Linke et al., 2005) yielded maximum fluid flow at Mound 11 as high as $200 \mathrm{~cm} \mathrm{yr}^{-1}$ at the centre of the seep (within microbial mat patches), while only approximately $10 \mathrm{~cm} \mathrm{yr}^{-1}$ was calculated for Mound 12. In contrast to these previous investigations, the present study derived fluid flow velocities of the two mounds from a comprehensive data set acquired during a single cruise. As the same methodological approach was 
Table 5. Mineralogy and stable isotope composition of carbonate samples from Mound 11 and 12 (cruise SO206). The standard deviation (SD) of lab standard is given.

\begin{tabular}{|c|c|c|c|c|c|c|c|c|c|c|c|}
\hline Site & Station & $\begin{array}{r}\text { Depth } \\
\text { (cmbsf) }\end{array}$ & $\begin{array}{r}\text { Total } \\
\text { carbonate } \\
(\mathrm{wt} \%)\end{array}$ & $\begin{array}{r}\text { Magnesian } \\
\text { calcite } \\
(\mathrm{wt} \%)\end{array}$ & $\begin{array}{c}\mathrm{mol} \% \text { of } \\
\mathrm{MgCO}_{3}\end{array}$ & $\begin{array}{l}\text { Calcite } \\
\text { (wt \%) }\end{array}$ & $\begin{array}{r}\text { Aragonite } \\
\text { (wt \%) }\end{array}$ & $\begin{array}{r}\text { Dolomite } \\
(\mathrm{wt} \%)\end{array}$ & $\delta^{13} \mathrm{C}$ & SD & $\delta^{18} \mathrm{O}$ SD \\
\hline Mound 11 & SO206-38 & $172-185$ & 54 & 44 & 14 & & 10 & & -27.14 & 0.03 & $\begin{array}{ll}5.65 & 0.05\end{array}$ \\
\hline Mound 11 & SO206-39 & 8 & 60 & 49 & 13 & & 12 & & -26.21 & 0.03 & $\begin{array}{ll}5.87 & 0.05\end{array}$ \\
\hline Mound 11 & SO206-39 & $10-12$ & 58 & 48 & 15 & & & 11 & -21.20 & 0.03 & 4.720 .05 \\
\hline Mound 11 & SO206-39 & 11 & 53 & 42 & 13 & & 11 & & -27.49 & 0.03 & $\begin{array}{ll}5.71 & 0.05\end{array}$ \\
\hline Mound 11 & SO206-39 & $20-25$ & 58 & 46 & 15 & & 13 & & -29.56 & 0.03 & $\begin{array}{ll}6.15 & 0.05\end{array}$ \\
\hline Mound 11 & SO206-39 & $26-30$ & 48 & & & & 48 & & -29.01 & 0.03 & $\begin{array}{ll}5.85 & 0.05\end{array}$ \\
\hline Mound 11 & SO206-39, shell & 25 & 17 & 6 & 12 & 7 & 11 & & -6.98 & 0.03 & 3.550 .05 \\
\hline Mound 11 & SO206-39, shell & $26-30$ & 31 & & & 12 & 19 & & -9.61 & 0.03 & 3.960 .05 \\
\hline Mound 12 & SO206-44 & 5-8 & 55 & 33 & 15 & & 13 & & -48.98 & 0.03 & 4.150 .05 \\
\hline Mound 12 & SO206-46 & $6-7$ & 54 & 39 & 15 & 27 & & & -45.70 & 0.03 & $4.48 \quad 0.05$ \\
\hline
\end{tabular}

Table 6. List of ${ }^{87} \mathrm{Sr} /{ }^{86} \mathrm{Sr}$ ratios, $\delta^{13} \mathrm{C}$, and $\delta^{18} \mathrm{O}$ of carbonate-dominated fragments from Mound 11 and 12 carbonates obtained during cruises M54, M66, and SO173. Second standard error $(2 \sigma)$ and standard deviations (SD) are given.

\begin{tabular}{|c|c|c|c|c|c|c|c|c|c|c|}
\hline Site & Station & Depth (cmbsf) & ${ }^{87} \mathrm{Sr} /{ }^{86} \mathrm{Sr}$ & $2 \sigma$ & $\delta^{13} \mathrm{C}$ & SD & $\delta^{18} \mathrm{O}$ & SD & Aragonite (wt \%) & Calcite (wt \%) \\
\hline Mound 11 & M54-155 A & 155 & 0.708829 & $1.4 \mathrm{E}-05$ & -14.14 & 0.02 & 3.18 & 0.09 & 10 & 90 \\
\hline Mound 11 & M54-155 B & 155 & 0.709049 & 7.0E-06 & -15.57 & 0.02 & 4.22 & 0.04 & 70 & 30 \\
\hline Mound 12 & M54-97-2 A & 353 & 0.709167 & 7.5E-06 & -46.28 & 0.02 & 3.56 & 0.04 & $>98$ & $<2$ \\
\hline Mound 12 & M54-97-2 B & 353 & 0.709164 & $6.1 \mathrm{E}-06$ & -46.87 & 0.02 & 3.62 & 0.04 & $>98$ & $<2$ \\
\hline Mound 12 & M66-3 213 A & 0 & 0.70909 & 7.0E-06 & -39.53 & 0.02 & 4.13 & 0.04 & 95 & 5 \\
\hline Mound 12 & M66-3 213 В & 0 & 0.709158 & $8.0 \mathrm{E}-06$ & -42.46 & 0.02 & 3.96 & 0.04 & $>98$ & $<2$ \\
\hline Mound 12 & SO173 110-1a & $50-60$ & 0.709114 & $2.1 \mathrm{E}-05$ & -49.13 & 0.02 & 3.29 & 0.04 & 90 & 10 \\
\hline Mound 12 & SO173 110-1b & $50-60$ & 0.709098 & 8.0E-06 & -48.61 & 0.02 & 3.24 & 0.04 & $>98$ & $<2$ \\
\hline Mound 12 & SO173 110-1 & $50-60$ & 0.709088 & 7.0E-06 & -47.50 & 0.02 & 3.09 & 0.04 & $>98$ & $<2$ \\
\hline \multirow[t]{2}{*}{ Mound 12} & SO173 110-1 & $50-60$ & 0.709097 & $6.0 \mathrm{E}-06$ & -48.58 & 0.02 & 3.27 & 0.04 & $>98$ & $<2$ \\
\hline & & Modern seawater* & 0.709176 & $1.5 \mathrm{E}-05$ & & & & & & \\
\hline
\end{tabular}

${ }^{*}$ IAPSO standard seawater was used to represent modern seawater ${ }^{87} \mathrm{Sr} /{ }^{86} \mathrm{Sr}$ ratio.

applied for both locations, measured and modelled results can be compared directly.

The applied modelling approach indicated an advective fluid flow 13 times larger at Mound 11 than Mound 12. The fluid velocity constrained using the numerical transportreaction model at Mound 11 (SO206-39) was $200 \mathrm{~cm} \mathrm{yr}^{-1}$, which is the same value as determined by Karaca et al. (2010) at this site. The modelled depth-integrated areal AOM rate for Mound 11 (station SO206-39) was similar to the measured rate (Table 4). Thus, the modelling approach is suitable to describe the rate of methane turnover and related biogeochemical processes at this station. The modelled AOM rate for station SO206-50 was approximately $66 \%$ lower than the measured one. Considering that the measured AOM rate at SO206-50 had a standard deviation of approximately $54 \%$, the measured and modelled results were still in good agreement.

For both stations at Mound 12, best-fit model results were obtained using a fluid flow velocity of $15 \mathrm{~cm} \mathrm{yr}^{-1}$. Linke et al. (2005) $\left(16 \mathrm{~cm} \mathrm{yr}^{-1}\right)$ and Karaca et al. (2010) $\left(10 \mathrm{~cm} \mathrm{yr}^{-1}\right)$ yielded similar results, which indicate that spatial variation of fluid advection is less pronounced than at Mound 11 .
As for Mound 11, measured and modelled areal AOM rates were generally similar for Mound 12 . However, the measured AOM rate for station SO206-46 was approximately $51 \%$ lower than predicted by the model. The data used to constrain the model were obtained from the same multiple corer deployment but using different cores from those used for rate measurements. Therefore, it may be that variations of AOM activity between individual MUC cores could explain the observed differences between measured and modelled areal AOM rates at both mounds.

Previous studies of seep sites at Hydrate Ridge showed considerable lateral sediment heterogeneity regarding AOM activity (Treude et al., 2003), which can also be assumed for the region off Costa Rica (Hensen et al., 2004; Linke et al., 2005; Schmidt et al., 2005). However, spatial heterogeneity of AOM activity is not accounted for in the current model approach, as it assumed that concentrations and consequently reaction rates only vary with sediment depth. Therefore, the deviation of measurement- and model-based AOM rate for station SO206-46 does not necessarily indicate that model accuracy was insufficient to describe the methane-related 
biogeochemical processes at Mound 12, but rather illustrates the spatial heterogeneity of sedimentary AOM activity.

It should be mentioned that the observed difference in $\mathrm{AOM}$ and SR rates between the two mounds, measured here in surface sediments covered by thick sulfur bacteria mats, illustrates the wide range of methane turnover that can be connected with this type of chemosynthetic habitat. Sulfur bacteria are capable of oxidizing sulfide (Jørgensen and Nelson, 2004), and are typically present at localities of high anaerobic methane turnover (Treude et al., 2003). Consequently, the sulfate, produced by microbial sulfide oxidation, is partially introduced into the sediment, thus adding to the amount of sulfate originating from seawater. The process of sulfide oxidation is not explicitly resolved in the model; however, it is mimicked by intense non-local transport of sulfate into the sediment; that is, sulfide oxidation occurs on top of the sediment column. Regardless of the ultimate source of sulfate (re-oxidation or bottom water), shallow downward mixing of bottom water is required to obtain measured AOM rates at Mound 11 and is also suggested by shallow concave-down type sulfate profile of the MUC core porewater (SO206-39) at this location. The variability of AOM rates underneath sulfur bacteria mats observed in our study calls for caution with respect to extrapolation of methane turnover rates based on visual seafloor observations.

\subsection{Carbonate mineralogy and isotope systematics}

The authigenic carbonates from Mound 11 and 12 are a direct result of methane-dependent microbial activity. Measurements and modelling of the current microbial methane and sulfate turnover can be utilized to constrain ongoing methane advection. In addition, the carbonate archive provides indications for the long-term fluid advection of the past.

The majority of carbonate nodules, obtained during SO206, were largely characterized by Mg-rich calcite as the dominant carbonate phase, followed by aragonite, thus representing typical seep carbonates (Han et al., 2004; Pierre et al., 2012). However, one carbonate sample from Mound 11 showed aragonite as the sole carbonate phase present (48 wt \% of the total sample). The chemical situation at which aragonite or magnesian calcite is primarily formed is not well constrained (Burton, 1993), but there is evidence that the combination of the carbonate saturation state and the $\mathrm{Mg} / \mathrm{Ca}$ ratio in solution largely define the carbonate precipitate mineralogy (De Choudens-Sánchez and González, 2009). In addition, Burton and Walter (1987) showed that a low bottom-water temperature of about $2.5^{\circ} \mathrm{C}$ may favour calcite precipitation. Furthermore, magnesian calcite could have replaced highly metastable aragonite (Pierre et al., 2012). The occurrence of dolomite in one of the Mound 11 carbonate nodules might be the result of locally enhanced microbial activity of sulfate-reducing bacteria (Krause et al., 2012; Pierre et al., 2012).
In order to constrain the prevailing fluid sources during precipitation, the equilibrium $\delta^{18} \mathrm{O}$ values for the present carbonate phases and bottom water were calculated. Based on the bottom-water conditions used $\left(8^{\circ} \mathrm{C},+0.2 \% \circ \delta^{18} \mathrm{O}\right)$, the equilibrium $\delta^{18} \mathrm{O}$ values for calcite, magnesian calcite, dolomite, and aragonite with water were 1.5, 2.4, 5.1, and $3.1 \%$, respectively. Considering the dominant carbonate phases of the samples, the measured $\delta^{18} \mathrm{O}$ values apparently exceeded the equilibrium values for bottom water (Table 5). However, the $\delta^{18} \mathrm{O}$ value of one shallow sample from Mound 11 , including magnesian calcite and dolomite, was close to the equilibrium $\delta^{18} \mathrm{O}$ values for dolomite. Therefore, it cannot be excluded that carbonate from this sample formed under considerable influence of bottom water. In contrast, the higher $\delta^{18} \mathrm{O}$ values of the remaining carbonates from Mound 11 indicate that precipitation occurred under considerable influence of a deep-source fluid, which is enriched in ${ }^{18} \mathrm{O}$ (Mavromatis et al., 2012). According to Hensen et al. (2004), the observed positive $\delta^{18} \mathrm{O}$ values of deep-source fluids from the study area are the result of clay-mineral dehydration at temperatures between 85 and $130^{\circ} \mathrm{C}$ at $\sim 12 \mathrm{~km}$ depth and subsequent upward fluid transport. The two bivalve shell fragments were close to the equilibrium $\delta^{18} \mathrm{O}$ value for aragonite bottom water, indicating that synthesis of the shell indeed occurred in the bottom water. The two carbonate samples obtained from Mound 12 also showed higher $\delta^{18} \mathrm{O}$ values than the equilibrium values for the dominant carbonate phases (Table 5). Yet, in comparison to Mound 11, the $\delta^{18} \mathrm{O}$ values of Mound 12 carbonates were closer to the equilibrium values, indicating that deep-source fluid was present during precipitation, but to a lesser extent than at Mound 11 .

In comparison to Mound 12, carbonate nodules at Mound 11 were less depleted in $\delta^{13} \mathrm{C}$, suggesting methane of thermogenic origin predominantly present during concretion formation (Schmidt et al., 2005). In principal, the $\delta^{13} \mathrm{C}$ values encountered in Mound 11 carbonates could also originate from organic matter degradation (Curtis, 1987). However, organic matter degradation is assumed to be a negligible sink for sulfate and a source of methane compared to SR and AOM fuelled by upward advection of methane-rich fluids in the study area (Karaca et al., 2010; Wallmann et al., 2006). Therefore, thermogenic methane is considered a primary inorganic carbon source in Mound 11 sediments. In contrast, methane of biogenic origin from a shallower source might have been causative for strongly depleted $\delta^{13} \mathrm{C}$ in Mound 12 carbonates (Hensen and Wallmann, 2005).

Han et al. (2004) identified five types of authigenic carbonate associated with fluid vents on the Costa Rica margin based on morphological, petrographic, and stable isotope criteria (referred to the PDB scale): chemoherm carbonates, seepage-associated concretions, gas-hydrate-associated concretions, as well as calcareous and dolomitic concretions. Regarding the isotopic composition, carbonate samples obtained for Mound 11 and 12 during the SO206 cruise can be divided into two groups (Fig. 5). Group 1 was comprised 
of Mound 11 carbonates samples, while group 2 included samples from Mound 12. Carbonates from group 1 were characterized by $\delta^{18} \mathrm{O}$ values between 5.6 and $6.7 \%$. Corresponding $\delta^{13} \mathrm{C}$ values ranged from -21 to $-29 \%$. According to the carbonate classification mentioned above, group 1 carbonate isotope composition is indicative of gas-hydrateassociated concretions $\left(\delta^{18} \mathrm{O} 5.2\right.$ to $6.8 \%$ o, $\delta^{13} \mathrm{C}-18.6$ to $-29.8 \%$ ); Han et al., 2004). This type of carbonate is characterized by layered Mg-rich calcite and aragonite precipitated into spaces previously occupied by gas hydrates before dissociation (Bohrmann et al., 2002; Suess, 2002). Bivalve shell material from Mound 11 was mainly composed of aragonite and organic components. Corresponding values of $\delta^{13} \mathrm{C}$ showed an isotopic signature considerably higher compared to the carbonates $(-6.9$ and $-9.7 \%$ ), indicating shell formation in seawater with atmospheric $\mathrm{CO}_{2}$ as a carbon source (Emrich et al., 1970). The carbonates from group 2 had a lower $\delta^{18} \mathrm{O}$ signature (4.1-4.5\%), while depletion of ${ }^{13} \mathrm{C}$ was stronger compared to group 1 ( -39 to $-49 \%$ ). According to Han et al. (2004), carbonates of group 2 are typical for seepage-associated concretions $\left(\delta^{18} \mathrm{O} 4.3\right.$ to $5.4 \%$ o, $\delta^{13} \mathrm{C}$ -44.6 to $-53.0 \%$ o). This type of carbonate occurs at or near the seafloor, forming small, individual carbonate blocks, concretions, and crusts of high $\mathrm{Mg}$ calcite.

The ${ }^{87} \mathrm{Sr} /{ }^{86} \mathrm{Sr}$ signature of the carbonate samples varied between the two mounds depending on the aragonite / calcite ratio (Table 6). The aragonite-dominated samples from Mound 12, representing 90 to $>98 \mathrm{wt} \%$ of the present carbonate, generally showed ${ }^{87} \mathrm{Sr} /{ }^{86} \mathrm{Sr}$ signatures in the range of modern seawater or slightly lower. Considering the variation of the ${ }^{87} \mathrm{Sr} /{ }^{86} \mathrm{Sr}$ encountered in carbonates from Mound 12, two groups can be distinguished (Fig. 6). One group, consisting of five samples, encompasses ${ }^{87} \mathrm{Sr} /{ }^{86} \mathrm{Sr}$ ratios slightly lower than modern seawater, represented by IAPSO standard seawater. The difference of ${ }^{87} \mathrm{Sr} /{ }^{86} \mathrm{Sr}$ between this group and IAPSO standard seawater was larger than the second standard error $(2 \sigma)$ of $1.5 \times 10^{-5}$ for IAPSO standard seawater. Therefore, it can be assumed that fluid, although to a small extend, contributed to the porewater during carbonate precipitation. Carbonates from this group were retrieved from 50 to $60 \mathrm{cmbsf}$, with the exception of one sample (M66-3 213 B), which was collected from the sediment surface. Consequently, precipitation of these carbonates occurred under seawater conditions with minor fluid contribution. In contrast, the three remaining carbonate samples showed ${ }^{87} \mathrm{Sr} /{ }^{86} \mathrm{Sr}$ rations similar to modern seawater, indicating precipitation under seawater conditions. Two of these carbonates were collected from $353 \mathrm{cmbsf}$, and one from the sediment surface.

In contrast, Mound 11 carbonate samples showed considerably lower ${ }^{87} \mathrm{Sr} /{ }^{86} \mathrm{Sr}$ ratios. This difference correlated with the amount of calcite present, as the $90 \mathrm{wt} \%$ calcitedominated sample showed a lower ${ }^{87} \mathrm{Sr} /{ }^{86} \mathrm{Sr}$ ratio compared to the sample containing $30 \mathrm{wt} \%$ calcite. The observed lower ${ }^{87} \mathrm{Sr} /{ }^{86} \mathrm{Sr}$ ratio, compared to seawater, of Mound 11 car-

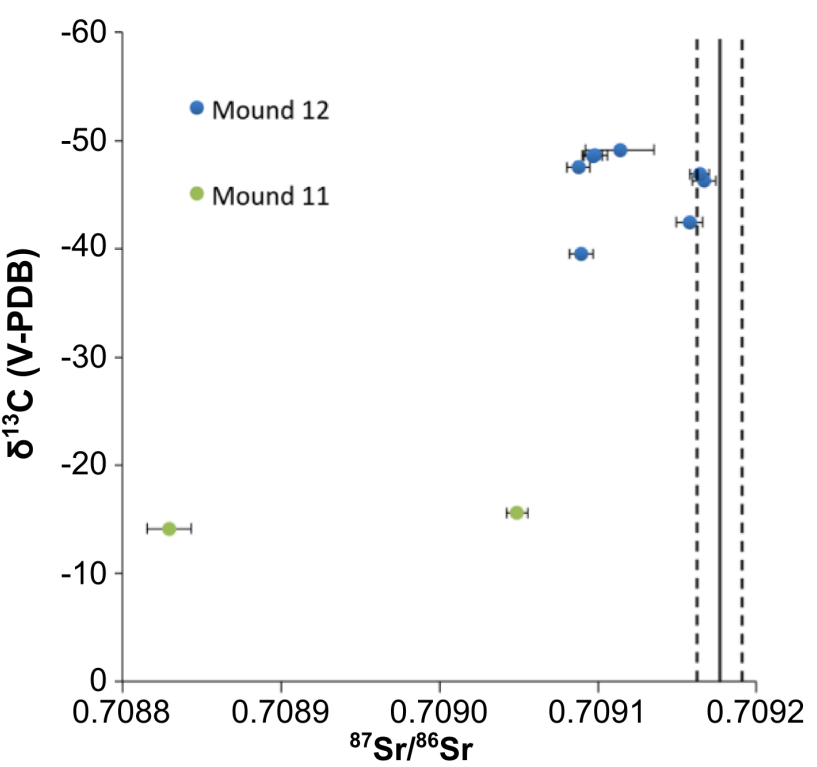

Fig. 6. $\delta^{13} \mathrm{C}$ vs. ${ }^{87} \mathrm{Sr} /{ }^{86} \mathrm{Sr}$ ratios of carbonate material sampled during cruises SO173/4, M66/3a, and M54/3a. Two standard deviations $(2 \sigma)$ of individual ${ }^{87} \mathrm{Sr} /{ }^{86} \mathrm{Sr}$ measurements are given. The solid line indicates the measured ${ }^{87} \mathrm{Sr} /{ }^{86} \mathrm{Sr}$ ratio of IAPSO standard seawater; the dotted lines represent $2 \sigma$. The standard deviation of $\delta^{13} \mathrm{C}$ measurements was $0.02 \%$ (symbols larger than error bars).

bonates formed under considerable influence of deep-source fluid, exposed to the weathering of abundant volcanic ashes in the sediment (Silver et al., 2000; Soeding et al., 2003; Kutterolf et al., 2008). The ${ }^{87} \mathrm{Sr} /{ }^{86} \mathrm{Sr}$ ratios of Mound 11 carbonates were slightly higher than reported porewater values of 0.708699 (23.5 cmbsf) (Scholz et al., 2010). In contrast, Mound 12 carbonates presumably precipitated under hydrological conditions dominated by seawater. The observed difference in the ${ }^{87} \mathrm{Sr} /{ }^{86} \mathrm{Sr}$ ratio provides independent evidence that the authigenic carbonates at Mound 11 were formed under influence of advecting fluid, while Mound 12 carbonates formed in a seawater environment with only small contributions of ascending fluid.

According to sediment petrographic interpretation, dating of volcaniclastic layers and uranium-thorium dating of carbonates from the two locations (Kutterolf et al., 2008), Mound 11 is considered to be currently active, implying that it has been expelling fluids and, potentially, mud onto the surrounding seafloor for at least the last $15 \mathrm{ka}$. In contrast, pelagic surface sediments $(131 \mathrm{~cm}$ thickness) at Mound 12 indicate that vertical mud transport has been inactive for the last $5 \mathrm{ka}$ (Kutterolf et al., 2008). The rate measurements presented in this study demonstrated recent methane-related microbial activity at both mounds. Consequently, Mound 12 also has to be considered as a site of active fluid venting, delivering sufficient methane to support related microbial activity. The present study demonstrated that fluid and methane migration at Mound 12 showed spatial variations, 
and therefore sampling of surface sediments could recover either pelagic or seep sediments, depending on where sampling instruments were deployed. During video surveys of Mound 12 surface sediments, we discovered both areas displaying chemosynthetic communities as well as areas devoid of such, which indicates heterogeneous fluid migration.

As both mounds are situated on the same fault zone, ascending fluids may originate from the same source (Mavromatis et al., 2012). Due to past or ongoing tectonic processes, the fluid pathway of Mound 12 might have been compromised, reducing deep-source fluid advection at this location. The slightly lighter $\delta^{18} \mathrm{O}$ values of Mound 12 carbonates suggest that fluids at this location represent a mixture of deep-source fluid with bottom water. In contrast, carbonate $\delta^{13} \mathrm{C}$ values indicated that fluids at Mound 11 are primarily charged with deep-source thermogenic methane.

\section{Summary}

Methane-charged fluid advection is causative for high microbial activity in surface sediments of the two neighbouring mounds, Mound 11 and 12, located at the Pacific continental margin off Costa Rica. Anaerobic oxidation of methane $(\mathrm{AOM})$ and sulfate reduction (SR) rates determined ex situ in surface sediments were one order of magnitude higher at Mound 11 compared to Mound 12. Differences in carbonate stable isotope composition and ${ }^{87} \mathrm{Sr} /{ }^{86} \mathrm{Sr}$ signatures of the two mounds indicated that ascending fluid at Mound 11 originated from a deep source transporting primarily thermogenic methane. In contrast, advecting fluids at Mound 12 were less prominent and primarily charged with biogenic methane from a shallower source. Our study demonstrated that direct measurements of microbial AOM and SR activity, in combination with numerical modelling and carbonate archives analysis, provide a suitable ground-truthing tool to support geophysical measurements in order to constrain spatial variations of methane-charged fluid flow at the Costa Rica continental margin.

\section{Supplementary material related to this article is available online at http://www.biogeosciences.net/11/507/ 2014/bg-11-507-2014-supplement.pdf.}

Acknowledgements. Funding for the present study was provided by the SFB-574 "Volatiles and Fluids in Subduction Zones" and "The Future Ocean" Cluster of Excellence funded by the German Research Foundation (DFG). We thank the captains and the crew of RV Sonne and RV Meteor as well as all staff members who supported work on board. We would like to acknowledge our colleagues A. Bleyer, B. Domeyer, R. Ebbinghaus, R. Surberg, E. Corrales-Cordero, and E. Piñero for porewater sampling and chemical analyses at sea and in land-based laboratories. J. Hommer, K. Kretschmer, and J. Farkas are thanked for radiotracer analysis. We also thank A. Kolevica, and L. Haxhiaj for isotope measurements. J. Heinze, N. Augustin, and M. Schmidt are thanked for their help during carbonate mineralogy analysis. We also thank I. Klaucke and R. W. Weinrebe for providing bathymetric data. $\mathrm{K}$. Lindhorst is thanked for the generation of bathymetric maps. M. Nuzzo was funded by the Portuguese Science and Technology Foundation (grant SFRH/BPD/44598/2008). This publication is contribution no. 270 of the Collaborative Research Centre 574 "Volatiles and Fluids in Subduction Zones" at Kiel University.

The service charges for this open access publication have been covered by a Research Centre of the Helmholtz Association.

Edited by: K. Küsel

\section{References}

Barnes, R. O. and Goldberg, E. D.: Methane Production and Consumption in Anoxic Marine-Sediments, Geology, 4(5), 297-300, 1976.

Bayon, G., Pierre, C., Etoubleau, J., Voisset, M., Cauquil, E., Marsset, T., Sultan, N., Le Drezen, E., Fouquet, Y.: Sr/Ca and Mg/Ca ratios in Niger Delta sediments: Implications for authigenic carbonate in cold seep environments, Mar. Geol., 241, 93-109, 2007.

Berner, R. A.: Early Diagenesis - A Theoretical Approach, Princeton University Press, Princeton, NJ, 1980.

Boetius, A., Ravenschlag, K., Schubert, C. J., Rickert, D., Widdel, F., Gieseke, A., Amann, R., Jorgensen, B. B., Witte, U., and Pfannkuche, O.: A marine microbial consortium apparently mediating anaerobic oxidation of methane, Nature, 407, 623-626, 2000.

Bohrmann, G., Greinert, J., Suess, E. and Torres, M.: Authigenic carbonates from the Cascadia subduction zone and their relation to gas hydrate stability, Geology, 26, 647-650, doi:10.1130/0091-7613(1998)026<0647:ACFTCS>2.3.CO;2, 1998.

Bohrmann, G., Heeschen, K., Jung, C., Weinrebe, W., Baranov, B., Cailleau, B., Heath, R., Hühnerbach, V., Hort, M., Masson, D., and Trummer, I.: Widespread fluid expulsion along the seafloor of the Costa Rica convergent margin, Terra Nova, 14, 69-79, 2002.

Boudreau, B. P.: Diagenetic Models and their Implementation: Modelling Transport and Reactions in Aquatic Sediments, Springer Verlag, Berlin, 1997.

Boudreau, B. P. and Marinelli, R. L.: A modelling study of discontinuous biological irrigation, J. Mar. Res., 52, 947-968, 1994.

Bowes, H. L. and Hornibrook, E. R. C.: Emission of highly 13Cdepleted methane from an upland blanket mire, Geophys. Res. Lett., 33, 1-4, 2006.

Burton, E. A. and Walter, L. M.: Relative precipitation rates of aragonite and $\mathrm{Mg}$ calcite from seawater: temperature or carbonate ion control?, Geology, 15, 111-114, 1987.

Burton, E. A.: Controls on marine carbonate cement mineralogy: Review and reassessment, Chem. Geol., 105, 163-179, 1993. 
Capo, R. C., Stewart, B. W., and Chadwick, O. A.: Strontium isotopes as tracers of ecosystems processes: Theory and methods, Geoderma, 82, 197-225, 1998.

Chuang, P.-C., Dale, A. W., Wallmann, K., Haeckel, M., Yang, T. F., Chen, N.-C., Chen, H.-C., Chen, H.-W., Lin, S., Sun, C.-H., You, C.-F., Horng, C.-S., Wang, Y., and Chung, S.-H.: Relating sulfate and methane dynamics to geology: Accretionary prism offshore SW Taiwan, Geochem. Geophys. Geosyst., 14, 25232545, doi:10.1002/ggge.20168, 2013,

Cline, J. D.: Spectrophotometric determination of hydrogen sulfide in natural waters, Limnol. Oceanogr., 14, 454-458, 1969.

Curtis, C.: Mineralogical Consequences of Organic Matter Degradation in Sediments: Inorganic/Organic Diagenesis, in Marine Clastic Sedimentology, Springer Netherlands, 108-123, 1987.

Dale, A. W., Sommer, S., Haeckel, M., Wallmann, K., Linke, P., Wegener, G., and Pfannkuche, O.: Pathways and regulation of carbon, sulfur and energy transfer in marine sediments overlying methane gas hydrates on the Opouawe Bank (New Zealand), Geochim. Cosmochim. Ac., 74, 5763-5784, doi:10.1016/j.gca.2010.06.038, 2010.

Dasch, E. J.:Strontium isotopes in weathering profiles, deep-sea sediments, and sedimentary rocks, Geochim. Cosmochim. Ac., 33, 1521-1552, 1969.

De Choudens-Sánchez, V. and González, L. A.: Calcite and aragonite precipitation under controlled instantaneous supersaturation: elucidating the role of $\mathrm{CaCO}_{3}$ saturation state and $\mathrm{Mg} / \mathrm{Ca}$ ratio on calcium carbonate polymorphism, J. Sediment. Res., 79, 363376, 2009.

Emrich, K., Ehhalt, D. H., and Vogel, J. C.: Carbon isotope fractionation during the precipitation of calcium carbonate, Earth Planet. Sci. Lett., 8, 363-371, 1970.

Fritz, P. and Smith, D. C. W.: The isotopic composition of secondary dolomites, Geochim. Cosmochim. Ac., 34, 1167-1173, 1970.

Goldsmith, J. R., Graf, D. L., and Heard, H. C.: Lattice constants of the calcium-magnesium carbonates, Am. Miner., 46, 453-457, 1961.

Greinert, J., Bohrmann, G., and Suess, E.: Gas Hydrate-associated carbonates and methane-venting at Hydrate Ridge?: Classification, distribution, and origin of authigenic lithologies, edited by: C. K. Paull and W. P. Dillon, Geophy. Monog. Series, 124, 9113, AGU, Washington DC, 2001.

Grossman, E. L. and $\mathrm{Ku}, \mathrm{T}$. L.: Carbon and oxygen isotope fractionation in biogenic aragonite: temperature effects, Chem. Geol., 59, 59-74, 1986.

Haeckel, M., Boudreau, B. P., and Wallmann, K.: Bubbleinduced porewater mixing: A 3-D model for deep porewater irrigation, Geochim. Cosmochim. Ac., 71, 5135-5154, doi:10.1016/j.gca.2007.08.011, 2007.

Han, X., Suess, E., Sahling, H., and Wallmann, K.: Fluid venting activity on the Costa Rica margin: new results from authigenic carbonates, Int. J. Earth Sci., 93, 596-611, doi:10.1007/s00531004-0402-y, 2004.

Henry, P., Le Pichon, X., Lallemant, S., Lance, S., Martin, J. B., Foucher, J. P., Fiala-Médioni, A., Rostek, F., Guilhaumou, N., Pranal, V., and Castrec, M.: Fluid flow in and around a mud volcano field seaward of the Barbados accretionary wedge: Results from Manon cruise, J. Geophys. Res., 101, 297-323, 1996.

Hensen, C., Nuzzo, M., Hornibrook, E., Pinheiro, L., Bock, B., Magalhaes, V., and Bruckmann, W.: Sources of mud vol- cano fluids in the Gulf of Cadiz-indications for hydrothermal imprint, Geochim. Cosmochim. Ac., 71, 1232-1248, doi:10.1016/j.gca.2006.11.022, 2007.

Hensen, C. and Wallmann, K.: Methane formation at Costa Rica continental margin-constraints for gas hydrate inventories and cross-décollement fluid flow, Earth Planet. Sc. Lett., 236, 41-60, doi:10.1016/j.eps1.2005.06.007, 2005.

Hensen, C., Wallmann, K., Schmidt, M., Ranero, C. R., and Suess, E.: Fluid expulsion related to mud extrusion off Costa Rica - A window to the subducting slab, Geology, 32, 201-204, 2004.

Jørgensen, B. B.: A comparison of methods for the quantification of bacterial sulphate reduction in coastal marine sediments: I. Measurements with radiotracer techniques, Geomicrobiol. J., 1, 11-27, 1978 .

Jørgensen, B. B. and Nelson, D. C.: Sulfide oxidation in marine sediments: Geochemistry meets microbiology, Geol. S. Am. S., 379, 63-81, 2004.

Joye, S. B., Boetius, A., Orcutt, B. N., Montoya, J. P., Schulz, H. N., Erickson, M. J., and Logo, S. K.: The anaerobic oxidation of methane and sulfate reduction in sediments from Gulf of Mexico cold seeps, Chem. Geol., 205, 219-238, doi:10.1016/j.chemgeo.2003.12.019, 2004.

Judd, A. G., Hovland, M., Dimitrov, L. I., Gil, S. G., and Jukes, V.: The geological methane budget at Continental Margins and its influence on climate change, Geofluids, 2, 109-126, 2002.

Kallmeyer, J., Ferdelman, T. G., Weber, A., Fossing, H., and Jørgensen, B. B.: A cold chromium distillation procedure for radiolabeled sulfide applied to sulfate reduction measurements, Limnol. Oceanogr-Meth., 2, 171-180, 2004.

Karaca, D., Hensen, C., and Wallmann, K.: Controls on authigenic carbonate precipitation at cold seeps along the convergent margin off Costa Rica, Geochem. Geophy. Geosy., 11, 1-19, doi:10.1029/2010GC003062, 2010.

Kim, S. T. and O'Neil, J. R.: Equilibrium and nonequilibrium oxygen isotope effects in synthetic carbonates, Geochim. Cosmochim. Ac., 61, 3461-3475, 1997.

Klaucke, I., Masson, D. G., Petersen, C. J., Weinrebe, W., and Ranero, C. R.: Multifrequency geoacoustic imaging of fluid escape structures offshore Costa Rica: Implications for the quantification of seep processes, Geochem. Geophy. Geosy., 9, Q04010, doi:10.1029/2007GC001708, 2008.

Kopf, A. J.:Significance of mud volcanism, Rev. Geophys., 40, 1005, doi:10.1029/2000RG000093, 2002.

Krause. S., Liebetrau, V., Gorb, S., Sánchez-Román, M., McKenzie, J. A., and Treude, T.:Microbial nucleation of Mg-rich dolomite in exopolymeric substances under modern seawater salinity: New insight into an old enigma, Geology, 40, 587-590, 2012.

Krüger, M., Treude, T., Wolters, H., Nauhaus, K., and Boetius, A.: Microbial methane turnover in different marine habitats, Palaeogeogr. Palaeocl., 227, 6-17, doi:10.1016/j.palaeo.2005.04.031, 2005.

Kutterolf, S., Liebetrau, V., Mörz, T., Freundt, A., Hammerich, T., and Garbe-Schönberg, D.: Lifetime and cyclicity of fluid venting at forearc mound structures determined by tephrostratigraphy and radiometric dating of authigenic carbonates, Geology, 36, 707, doi:10.1130/G24806A.1, 2008.

Linke, P., Wallmann, K., Suess, E., Hensen, C., and Rehder, G.: In situ benthic fluxes from an intermittently active mud volcano at 
the Costa Rica convergent margin, Earth Planetary Sc. Lett., 235, 79-95, doi:10.1016/j.eps1.2005.03.009, 2005.

Mau, S., Sahling, H., Rehder, G., Suess, E., Linke, P., and Soeding, E.: Estimates of methane output from mud extrusions at the erosive convergent margin off Costa Rica, Mar. Geol., 225, 129_ 144, 2006.

Mavromatis, V., Botz, R., Schmidt, M., Liebetrau, V., and Hensen, C.: Formation of carbonate concretions in surface sediments of two mud mounds, offshore Costa Rica - a stable isotope study, Int. J. Earth Sc., 1-14, doi:10.1007/s00531-012-0843-7, 2012.

McArthur, J. M., Thirlwall, M. F., Engkilde, M., Zinsmeister, W. J., and Howarth, R. J.: Strontium isotope profiles across K/T boundary sequences in Denmark and Antarctica, Earth Planetary Sci. Lett., 160, 179-192, doi:10.1016/S0012-821X(98)00058-2, 1998.

McAullife, C.: GC Determination of solutes by multiple phase equilibration, Chemical Technolgy, 1, 46-51, 1971.

Mörz, T., Fekete, N., Kopf, A. J., Brueckmann, W., Kreiter, S., Huehnerbach, V., Masson, D. G., Hepp, D. A., Schmidt, M., Kutterolf, S., Sahling, H., Abegg, F., Spiess, V., Suess, E., and Ranero, C. R.: Styles and productivity of mud diapirism along the Middle American Margin, Part II, Mound Culebra and Mounds 11 and 12, in Mud volcanoes, geodynamics and seismicity, edited by: G. Martinelli and B. Panahi, 49-76, Springer, Dordrecht, the Netherlands, 2005.

Naehr, T. H., Eichhubl, P., Orphan, V. J., Hovland, M., Paull, C. K., Ussler, W., Lorenson, T. D., and Greene, H. G.: Authigenic carbonate formation at hydrocarbon seeps in continental margin sediments: A comparative study, Deep-Sea Res. Pt. I, 54, 12681291, 2007.

Niemann, H., Lösekann, T., De Beer, D., Elvert, M., Nadalig, T., Knittel, K., Amann, R., Sauter, E. J., Schlüter, M., Klages, M., Foucher, J. P., and Boetius, A.: Novel microbial communities of the Haakon Mosby mud volcano and their role as a methane sink., Nature, 443, 7113, doi:10.1038/nature05227, 2006.

Peckmann, J., Reimer, A., Luth, U., Luth, C., Hansen, B. T., Heinicke, C., Hoefs, J., and Reitner, J.: Methane-derived carbonates and authigenic pyrite from the northwestern Black Sea, Mar. Geol., 177, 129-150, 2001.

Pierre, C., Blanc-Valleron, M.-M., Demange, J., Boudouma, O., Foucher, J.-P., Pape, T., Himmler, T., Fekete, N., and Spiess, V.:Authigenic carbonates from active methane seeps offshore southwest Africa, Geo-Mar. Lett., 32, 501-513, 2012.

Ranero, C. R., Grevemeyer, I., Sahling, H., Barckhausen, U., Hensen, C., Wallmann, K., Weinrebe, W., Vannucchi, P., von Huene, R. \& McIntosh, K.: Hydrogeological system of erosional convergent margins and its influence on tectonics and interplate seismogenesis, Geochem. Geophy., 9, Q03S04, doi:10.1029/2007GC001679, 2008.

Ranero, C. R. and Von Huene, R.: Subduction erosion along the Middle America convergent margin, Nature, 404, 748-52, doi:10.1038/35008046, 2000.

Saffer, D. M. and Tobin, H. J.: Hydrogeology and mechanics of subduction zone forearcs: Fluid flow and pore pressure, Annu. Rev. Earth Pl. Sc., 39, 157-186, 2011.
Schmidt, M., Hensen, C., Mörz, T., Müller, C., Grevemeyer, I., Wallmann, K., Maub, S., and Kaule, N.: Methane hydrate accumulation in "Mound 11" mud volcano, Costa Rica forearc, Mar. Geol., 216, 83-100, 2005.

Schoell, M.: Multiple origins of methane in the Earth, Chem. Geol., 71, 1-10, doi:10.1016/0009-2541(88)90101-5, 1988.

Scholz, F., Hensen, C., De Lange, G. J., Haeckel, M., Liebetrau, V., Meixner, A., Reitz, A., and Romer, R. L.: Lithium isotope geochemistry of marine pore waters - Insights from cold seep fluids, Geochim. Cosmochim. Ac., 74, 3459-3475, 2010.

Silver, E., Kastner, M., Fisher, A., Morris, J., McIntosh, K., and Saffer, D.: Fluid flow paths in the Middle America Trench and Costa Rica margin, Geology, 28, 679-682, 2000.

Soeding, E., Wallmann, K., Suess, E., Fluh., E.: FS Meteor cruise report M 54/2-3:Caldera-Curacao: GEOMAR Report 111, 366 pp., 2003.

Spiker, E. C. and Hatcher, P. G.: Carbon isotope fractionation of sapropelic organic matter during early diagenesis, Org. Geochem., 5, 283-290, 1984.

Suess, E.: Gashydrat - Eine Verbindung aus Methan und Wasser, Nova Ac. Lc., 85, 123-146, 2002.

Suess, E.: Handbook of hydrocarbon and lipid microbiology, edited by: Timmis, K. N., Springer-Verlag, Berlin, Heidelberg, 2010.

Tarutani, T., Clayton, R. N., and Mayeda, T. K.: The effect of polymorphism and magnesium substitution of oxygen isotope fractionation between calcium carbonate and water, Geochim. Cosmochim. Ac., 33, 987-996, 1969.

Thauer, R. K.: Biochemistry of Methanogenesis: a Tribute to Marjory Stephenson, Microbiology, 144, 2377-2406, 1998.

Tishchenko, P., Hensen, C., Wallmann, K., and Wong, C. S.: Calculation of the stability and solubility of methane hydrate in seawater, Chem. Geol., 219, 37-52, 2005.

Torres, M. E., Wallmann, K., Tréhu, a. M., Bohrmann, G., Borowski, W. S., and Tomaru, H.: Gas hydrate growth, methane transport, and chloride enrichment at the southern summit of Hydrate Ridge, Cascadia margin off Oregon, Earth Planet. Sc. Lett., 226, 225-241, doi:10.1016/j.epsl.2004.07.029, 2004.

Treude, T., Boetius, A., Knittel, K., Wallmann, K., and Barker Jørgensen, B.: Anaerobic oxidation of methane above gas hydrates at Hydrate Ridge, NE Pacific Ocean, Mar. Ecol.-Prog. Ser., 264, 1-14, doi:10.3354/meps264001, 2003.

Treude, T., Kru, M., and Jørgensen, B. B.: Environmental control on anaerobic oxidation of methane in the gassy sediments of Eckernförde Bay (German Baltic), Limnol. Oceanogr., 50, 17711786, 2005.

Wallmann, K., Aloisi, G., Haeckel, M., Tishchenko, P., Pavlova, G., Greinert, J., Kutterolf, S., and Eisenhauer, A: Silicate weathering in anoxic marine sediments, Geochim. Cosmochim. Ac., 72, 2895-2918, doi:10.1016/j.gca.2008.03.026, 2008.

Wallmann, K., Drews, M., Aloisi, G., and Bohrmann, G.: Methane discharge into the Black Sea and the global ocean via fluid flow through submarine mud volcanoes, Earth Planet. Sc. Lett., 248, 545-560, doi:10.1016/j.eps1.2006.06.026, 2006.

Whiticar, M. J.: Carbon and hydrogen isotope systematics of bacterial formation and oxidation of methane, Chem. Geol., 161, 291314, 1999. 